\title{
Do Returnee Executives Value Corporate Philanthropy? Evidence from China
}

\author{
Lin Zhang ${ }^{1} \cdot$ Yuehua $\mathrm{Xu}^{2}$ (1) $\cdot$ Honghui Chen ${ }^{3}$
}

Received: 15 February 2020 / Accepted: 8 June 2021 / Published online: 18 June 2021

(c) The Author(s), under exclusive licence to Springer Nature B.V. 2021

\begin{abstract}
While past studies have enriched our understanding of the impact of returnee executives on firm market strategy and outcomes, we know relatively little about the relationship between returnee executives and firm nonmarket strategies. Grounded in upper echelons theory, this study explores the relationship between returnee executives and corporate philanthropy, the latter of which is an important nonmarket strategy in emerging economies such as China. Using data on publicly listed Chinese companies from 2010 to 2017, we find that the proportion of returnee executives is negative related to corporate philanthropy. We also find that this negative relationship is strengthened by executive ownership, but weakened by corporate prominence and political connections. Our study makes important theoretical contributions to strategic leadership research, upper echelons theory, and the literature of corporate philanthropy. The managerial implications are also discussed.
\end{abstract}

Keywords Corporate philanthropy $\cdot$ Returnee executives $\cdot$ Upper echelons $\cdot$ China

\section{Introduction}

Returnees are defined as people who have studied and/or worked in other countries (typically in developed countries such as the U.S.) and then returned to their home country (Li et al., 2012). Because of economic development and preferential policies toward returnees in emerging economies, international human mobility from developed countries to emerging economies has increased significantly in the last decade (Lin et al., 2016). For example, more than 5 million overseas Chinese had returned to China by $2018 .{ }^{1}$

Yuehua Xu

xuyueh@sdu.edu.cn

Lin Zhang

zhanglin6@scut.edu.cn

Honghui Chen

lnschh@mail.sysu.edu.cn

1 School of Business Administration, South China University of Technology, 381 Wushan Road, Tianhe District, Guangzhou 510641, People's Republic of China

2 School of Management, Shandong University, 27 Shandanan, Licheng District, Jinan 250100, People's Republic of China

3 School of Business, Sun Yat-Sen University, 135

Xingangxi Road, Haizhu District, Guangzhou 510275,

People's Republic of China
After returning to their home country, some returnees may establish their own businesses, while others often choose to work for big companies. Given that returnees often play an important role in the economic development of emerging economies (Dai \& Liu, 2009), it is very necessary for us to examine the influence of returnees in these economies.

A host of studies have examined the impact of returnees, predominantly taking the knowledge-based view and focusing on firm market strategy, such as innovation (e.g., Lin et al., 2014; Liu et al., 2010) and exports (e.g., Filatotchev et al., 2009), and on firm-level outcomes such as financial performance (e.g., Dai \& Liu, 2009; Li et al., 2012; Wright et al., 2008). While the extant research has enriched our understanding of how returnees affect market strategy and organizational outcomes, an important issue that remains less explored is the relationship between returnee executives and firm nonmarket strategies in emerging economies. A nonmarket strategy refers to "a concerted pattern of actions taken in the nonmarket environment to create value by improving its overall performance" (Baron, 1995: 47). Such actions often change "the institutional or societal context of economic competition" (Mellahi et al., 2016: 144). Given the important role of nonmarket strategy in obtaining strategic resources for firms in emerging economies (Mellahi

\footnotetext{
$\overline{1}$ http://edu.people.com.cn/n1/2019/0402/c1053-31009898.html.
} 
et al., 2016), it is imperative to explore the relationship between returnee executives and firm nonmarket strategy.

We develop a theoretical framework to examine the relationship between returnee executives and firm nonmarket strategies by drawing on insights from upper echelons theory (Hambrick \& Mason, 1984). Building on the premise that "executives' experiences, values, and personalities greatly influence their interpretations of the situations they face and, in turn, affect their choices" (Hambrick, 2007: 334), the upper echelons theory suggests that the background characteristics of top executives can predict the decisions and outcomes of the firm (Hambrick \& Mason, 1984). Following the recent view on this theory that the characteristics of the collective executives better explain firm strategies than that of the individual top executive (Beckman \& Burton, 2011; Hambrick, 2007), we focus on the collective returnee experience of top executives.

We choose corporate philanthropy as the key outcome variable of returnee executives, which is an important nonmarket strategy in emerging economies (Zhang et al., 2020). Corporate philanthropy refers to the voluntary, unconditional transfer of cash or other assets by firms for public purposes (Gautier \& Pache, 2015). While earlier studies often viewed it as a component of corporate social responsibility (hereafter "CSR") (Carroll, 1979; Dahlsrud, 2008; Wood, 1991), recent studies have highlighted that corporate philanthropy plays more important strategic roles in meeting the expectations of some key stakeholders, particularly in emerging economies such as China (e.g., Li et al., 2015; Lindgreen et al., 2009a; Wang \& Qian, 2011; Zhang et al., 2020). We first propose that firms donate less to philanthropic causes when they have a higher proportion of returnee executives, because returnee executives may be less likely than local executives to recognize the strategic value of philanthropy in emerging economies. Specifically, returnee executives who have studied/worked in developed economies tend to be deeply influenced by the view of comprehensive CSR in these economies, a view that treats corporate philanthropy as a component of CSR and proposes balancing the different aspects of CSR (Carroll, 1979; Freeman, 1984, 1999). Additionally, due to differences in strategic practices between developed and emerging economies (Li et al., 2012), we expect that returnees may overlook the strategic implications of corporate philanthropy in emerging economies.

Moreover, based on the key argument in upper echelon theory that the strength of executives' influence depends on how much discretion executives have (Hambrick, 2007; Hambrick \& Finkelstein, 1987), we propose that managerial discretion can affect the relationship between returnee executives and corporate philanthropy. Specifically, we propose that the relationship is strengthened by executive ownership, which indicates more managerial discretion, but weakened by corporate prominence and political connections, which constrain managerial discretion through greater expectation and scrutiny from the public and the government.

As one of the largest emerging economies, China provides an excellent context to test our theoretical model. First, the country's rapid economic development and preferential policies toward returnees have brought a rapid increase in the number of returnees in recent years, enabling us to examine the relationship between returnee executives and corporate philanthropy. Second, corporate philanthropy is often an important strategy to help firms obtain legitimacy in China (Li et al., 2015; Wang \& Qian, 2011), which may not be the case in developed countries. Thus, returnee executives and local executives may have diverging views on the strategic importance of corporate philanthropy, making returnee executives a salient factor in decisions on corporate philanthropy in China. We conduct our empirical analysis on the panel data for China's A-share listed companies over the eight years from 2010 to 2017.

Our study makes several important contributions. First, we contribute to the literature on strategic leadership (Cannella et al., 2009) by demonstrating that nonmarket strategic actions could be an important outcome of strategic leadership in emerging economies. Past studies mainly focused on how top executives may promote firm market strategies (e.g., Cain et al., 2015; Filatotchev et al., 2009; Liu et al., 2010; Souitaris \& Maestro, 2010). Our finding about the relationship between returnee executives and corporate philanthropy demonstrates that the experience of executives is also related to firm nonmarket strategies, thus enriching our understanding about the impact of strategic leadership. In a similar vein, by highlighting the roles returnees may play in affecting firm strategic decisions related to "their home country's social development" (Han et al., 2019: 858), it also contributes to the literature of returnees.

Second, we advance the literature on corporate philanthropy in particular and CSR in general. Our study enriches the understanding about the determinants of corporate philanthropy, which has received relatively limited attention in the extant literature (Dennis et al., 2009; Li et al., 2015). In addition, by providing evidence for the different impacts of returnee executives on the overall CSR and on corporate philanthropy, our study extends the small, but growing, body of research regarding corporate philanthropy as an increasingly strategic component of CSR (Fry et al., 1982; Wang \& Qian, 2011).

Third, we extend upper echelons theory (Hambrick, 2007; Hambrick \& Mason, 1984). By conceptually elaborating and empirically validating the relationship between returnee executives and corporate philanthropy, it spotlights demographic heterogeneity in the executive team as a key characteristic affecting strategic choices made by the firm (Beckman \& Burton, 2011; Hambrick, 2007), thereby differing from past studies that focused on the characteristics 
of individual executives or boards of directors. Moreover, most previous studies of managerial discretion have been conducted in Western contexts (e.g., Finkelstein \& Hambrick, 1990). Examining of the impact of returnee executives in China offers an opportunity to discover additional discretion-limiting factors that are deeply embedded in the particular context, such as political connections. In this way, our study broadens the scope of managerial discretion through deep contextualization.

\section{Theory and Hypotheses}

\section{Returnee Executives and the Impacts}

With the globalization of markets and liberalization of the transnational movement of skilled labor, scholars have paid increasing attention to returnees, about whom there are two general views. The positive view highlights the advantages of returnees, and argues that their scientific and technical training brings superior knowledge and skills which may promote firm performance (Liu et al., 2010; Wright et al., 2008). In addition, their international experience may enable them to propagate foreign practices in emerging markets (Han et al., 2019). In contrast, the negative view proposes that due to the rapid changes that have occurred in emerging markets and the differences between them and developed markets, returnees may lack local knowledge and connections, which could adversely affect firm performance ( $\mathrm{Li}$ et al., 2012).

Extant studies have provided empirical support for the above two views by exploring the impact of returnees on corporate strategy and organizational outcomes. For example, Filatotchev et al. (2009) found that technology ventures founded by returnees tend to have higher export intensity than those founded by locals. Liu et al. (2010) found that the innovation performance of local firms in emerging markets is positively associated with the presence of returnee entrepreneurs. Li et al. (2012) found that contextual factors such as state ownership and venture age can improve the net effect of returnee executives on venture performance by reducing their disadvantages. Recently, a few studies have started to examine the effects of returnees on CSR (e.g., Han et al., 2019; Zhang et al., 2018). These studies have argued that returnee executives have a greater awareness and understanding of CSR than local executives do, and thus commit the firm to more CSR activities. Consistent with this logic, they have found that firms led by returnee executives often exhibit higher levels of CSR than those led by local executives (Han et al., 2019). Although existing studies have extended our understanding of the outcomes of returnee executives, they have mainly focused on the impact on market strategies and the general CSR, and have largely neglected the impact on the nonmarket strategies of firms. Given the important role of nonmarket strategy in emerging economies (Mellahi et al., 2016), it is imperative to examine the relationship between returnee executives and firm nonmarket strategy. To address this research gap, this study aims to explore the effect of returnee executives on corporate philanthropy, the latter of which is often strategically used in emerging economies "as a means of managing a firm's position of power and legitimacy in the eyes of the influential player" (Li et al., 2015: 401).

\section{Corporate Philanthropy as a Nonmarket Strategy in China}

Although corporate philanthropy is only one component of CSR (Carroll, 1979; Dahlsrud, 2008; Sarkar \& Searcy, 2016; Singh et al., 2017), it has more strategic implications in emerging economies, thus can be regarded as a type of nonmarket strategy in such a context. In particular, it plays a very important role in pleasing key stakeholders (e.g., government and the public) and gaining legitimacy in emerging economies such as China (Li et al., 2015; Zhang et al., 2021). It is thus more valued by firms in such countries (Zhang et al., 2020). Empirical studies have provided evidence that corporate philanthropy is more valued in some emerging economies than in developed countries (Lindgreen et al., 2009a). For example, Amaeshi et al. (2006) found that unlike firms in developed countries, firms in Nigeria emphasize philanthropic responsibilities above economic, ethical, and legal responsibilities. Kusku and Zarkada-Fraser (2004) found that firms in Turkey attach more importance to corporate philanthropy than firms do in Australia. In the next section, we elaborate on the strategic implications of corporate philanthropy in China.

Unlike in developed countries, CSR is a relatively new concept in China. Since the implementation of the reform and opening-up policy in China in 1978, China has become economy-oriented, leading to ignorance of CSR. It was not until the 2000s that CSR began to be taken seriously in China due to the severe results of Chinese firms' socially irresponsible corporate behavior (e.g., labor scandals, product safety, and air pollution) and criticism from overseas (Gao, 2011). Thus, public awareness of CSR in China has lagged behind that of developed countries, where the concept arose much earlier.

However, although overall CSR is relatively underdeveloped, corporate philanthropy has never been suspended in China. Chinese firms view corporate philanthropy quite differently from their counterparts in developed countries, and value it far more than other components of CSR. From 2001 to 2011, 5.84\% of Chinese A-share listed firms gave over $1.5 \%$ of their trailing 3 -year net earnings to charity, 
compared with only $2.63 \%$ of American firms did. ${ }^{2}$ In addition, corporate donations comprise a high proportion of total social giving in China, unlike in developed countries. For example, in 2018, corporate philanthropy accounted for $61.89 \%$ of total social giving in China, compared with $4.69 \%$ in the U.S. ${ }^{3}$ Even loss-making firms donate generously in China. Huangpu Recycling Resources Company is a typical example. The company suffered a deficit each year from 2004 to 2009 with a debt-to-asset ratio of nearly $95 \%$, yet it donated 313 million RMB in 2009. ${ }^{4}$ Similarly, Li et al. (2016) found that private listed firms in China with declining performance tend to engage more in corporate philanthropy. Wang et al. (2014) found that Chinese firms undertook more corporate philanthropy when they failed to meet their performance aspirations.

Corporate philanthropy is more valued by Chinese firms than by Western firms because it is deeply rooted in the cultural, political, and governance systems of China, making it an important nonmarket strategy for firms to obtain legitimacy from the public and the government. First, Chinese culture encourages good deeds (e.g., philanthropy). Traditionally, the Chinese are deeply influenced by Buddhist, Daoist, and Confucian philosophies. Buddhists believe that compassion is a principal virtue in life and that individuals should be kind-hearted and benevolent. Similarly, Daoism emphasizes awareness of each other's needs. In Confucianism, a person who spreads bounty or rescues people is often considered to be a sage (Du et al., 2014; Wang \& Qian, 2011). In addition, the Chinese are deeply influenced by the more recent communist view that there should be no disparity in the distribution of wealth in society (Wang \& Qian, 2011). Although the rapid development of the Chinese economy has resulted in a change in public opinions of the wealthy, Chinese people are still deeply influenced by traditional values and communist ideology. Chinese culture is high in collectivism, ${ }^{5}$ emphasizing interdependence and the benefit of the group, community, or society over individual gain. Therefore, Chinese stakeholders of firms are likely to embrace those who contribute generously and criticize those who contribute little. For example, Vanke, one of the largest Chinese real estate companies, donated 2 million RMB to

\footnotetext{
${ }^{2}$ Data for China are sourced from the CSMAR database, and data for the U.S. are from the Kinder, Lydenberg, Domini, and Co. (KLD) database. These data are available from 1991 to 2011. Although the absolute amount of corporate philanthropy is lower in China than in the U.S., corporate philanthropy accounts for a higher percentage of firm earnings in China compared with the U.S., despite much lower per capita GDP and firm earnings in China than in the U.S.

${ }^{3}$ Data for China are from http://www.charity.gov.cn; data for the U.S. are from http://www.givinginstitute.org/donations.

${ }^{4}$ http://news.ifeng.com/society/special/chenguangbiao/.

5 https://www.hofstede-insights.com/country-comparison/china/.
}

relief efforts following the Wenchuan earthquake, but the public strongly criticized this as a relatively small donation. In contrast, the public circulated an article from the Web praising JDB Group for donating 100 million RMB, which sharply increased the company's sales within days (Wang \& Qian, 2011). Therefore, corporate philanthropy is an effective way for firms to obtain legitimacy with the public in China.

Second, corporate philanthropy is an ideal way for firms to cultivate a good relationship with the government in China (Gao \& Hafsi, 2015; Li et al., 2015; Wang \& Qian, 2011). On the one hand, corporate philanthropy is highly needed by the government in China. As China is so vast that there are generally insufficient government resources to provide community and social welfare projects, the Chinese government relies heavily on corporate philanthropy to alleviate such resource shortages (Dickson, 2003), and may even assign donation tasks to firms in charitable events (Li et al., 2015; Zhang et al., 2016). Thus, corporate philanthropy, which can reduce the Chinese government's financial burden for building new schools, better roads, or other similar projects is often highly appreciated by the government in China (Dickson, 2003; Wang \& Qian, 2011). On the other hand, corporate philanthropy is highly visible to the government in China. Unlike developed countries, China has few donation channels for firms to choose from except for government-organized charitable organizations or government departments. As the Chinese government imposes tight restrictions on the establishment and operation of charitable organizations, purely private and corporate charitable organizations face tremendous hurdles (Li et al., 2015). As a result, most charitable organizations in China are government-organized with executives designated by the government, who are usually former officials of the Department of Civil Affairs (Feng, 2015). For example, the most prominent charitable organizations, such as China Charity, the Red Cross Society of China, and the China Soong Ching Ling Foundation, are all established and controlled by the government (Zhang et al., 2016). Moreover, according to the Public Welfare Donations Law, government departments above county level are allowed to receive donations during natural disasters (Feng, 2015). Thus, firm donations which are made mainly through government-organized charitable organizations or government departments in China are highly visible to the Chinese government.

Given the inefficient market structures, severe political interference, and political uncertainty that arise in China's unique institutional setting, political legitimacy is important for the survival and success of Chinese firms (Park $\&$ Luo, 2001). Thus, Chinese firms have a strong motivation to cultivate a good relationship with the government. However, unlike in developed countries, corporate political activities (e.g., lobbying and campaign contributions) are 
Fig. 1 Theoretical model

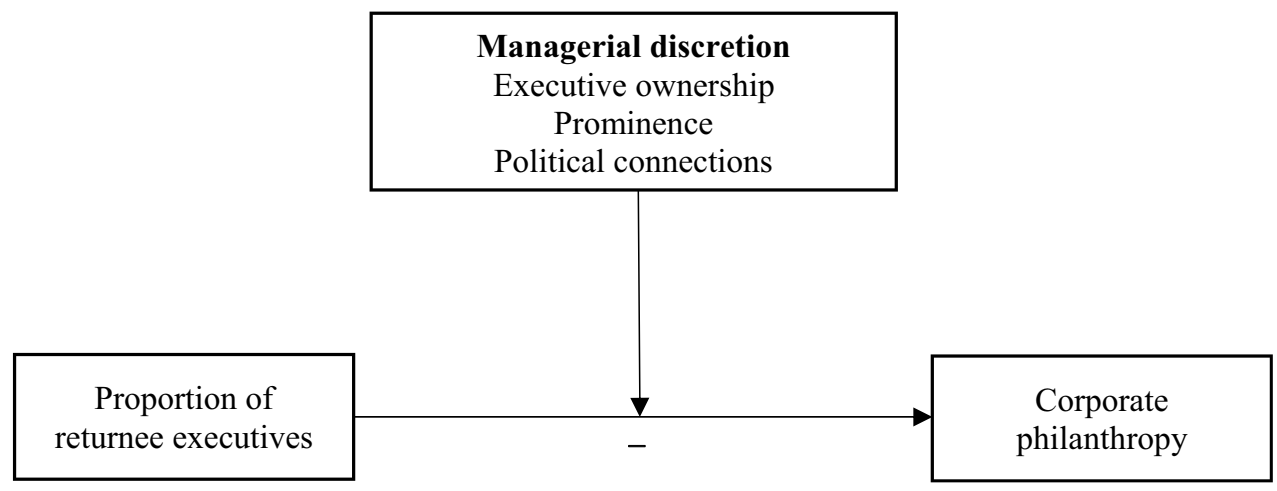

not allowed in China (Gao, 2006). Corporate philanthropy is one of the few nonmarket strategies permitted in China (He et al., 2007). The government may reward firms that make generous contributions with preferential treatment, such as access to bank loans, easier project approval, and tax benefits (Ma \& Parish, 2006). To sum up, corporate philanthropy is an important nonmarket strategy to gain legitimacy with the public and government in emerging economies such as China (Wang \& Qian, 2011).

\section{Hypotheses}

We draw on insights from upper echelons theory to explore the relationship between returnee executives and corporate philanthropy. Rooted in March and Simon's (1958)'s seminal insight that decision-makers are only boundedly rational, upper echelons theory provides a theoretical foundation to predict firm behaviors and outcomes (Carpenter et al., 2004; Hambrick, 2007). The central premise of upper echelons theory comprises two interconnected components: (1) executives act on the basis of their personalized interpretation of the strategic situation they face; and (2) this personalized construal is a function of the executives' experiences, values, and personalities (Hambrick, 2007; Hambrick \& Mason, 1984). Among the studies adopting the upper echelon theory, while most focus on the influence of individual executives, such as CEOs or entrepreneurs (Koch-Bayram \& Wernicke, 2018; Liu et al., 2021; Tang et al., 2018), on firm strategic choices, recent ones advocate a focus on the collective attributes of the entire management team (Beckman \& Burton, 2011). It is because "attention to executive groups, rather than to individuals, often yields better explanations of organizational outcomes" (Hambrick, 2007: 334).

One important collective attributes of top executives affecting firms' decisions and outcomes is executives' overseas experience (Lin et al., 2016). Corporate philanthropy is an important nonmarket strategy in emerging economies (Zhang et al., 2020). The current study focuses on returnee executives and tries to explore the relationship between returnee executives and corporate philanthropy. Based on upper echelons theory, we propose that returnee executives' overseas experience may impact their personalized interpretation of corporate philanthropy, thus affecting firms' decision on corporate philanthropy.

In the literature on upper echelons theory, managerial discretion is an important factor that may enable or constrain the influence of top executives on organizational outcomes (Hambrick, 2007; Hambrick \& Finkelstein, 1987). Many studies have shown that managerial discretion is a pivotal moderator of upper echelon predictions (e.g., Li \& Tang, 2010; Wu et al., 2015). Following this stream of literature, we identified three indicators of managerial discretion that can strengthen or weaken the relationship between returnee executives and corporate philanthropy. They are executive ownership, prominence, and political connections. Figure 1 illustrates our theoretical model.

\section{Returnee Executives and Corporate Philanthropy}

The current study focuses on returnee executives and aims to examine the relationship between returnee executives and corporate philanthropy. Specifically, we propose that the proportion of returnee executives is negatively related to corporate philanthropy for two reasons.

First, studying or working abroad exposes executives to the view of comprehensive CSR in developed countries. The last 30 years have witnessed CSR develop from an irrelevant and often frowned-upon idea into an orthodox and widely accepted concept in developed countries. Nowadays, most firms in developed countries have a comprehensive view of how to undertake CSR activities and corporate philanthropy (Carroll, 2008; Lee, 2008). Firms in developed countries tend to regard corporate philanthropy as a small proportion of their overall CSR and consider it only when they have performed well in the other more fundamental types of responsibility (Garriga \& Mele, 2004). Various empirical studies of CSR in developed countries support the view that corporate philanthropy is the most peripheral of the various CSR components (Lindgreen et al., 2009a, b; Smith et al., 2001). In addition, firms in developed countries place more 
emphasis on qualitative than quantitative aspects of their philanthropic programs (Maon et al., 2009). They tend to donate to philanthropic programs that have a positive, longterm social impact on the community (Porter \& Kramer, 1999), resulting in a prevalence of corporate charitable funds in developed countries (Feng, 2015). Such comprehensive view of CSR is consistent with the pyramid of CSR (Carroll, 1979, 1991) and stakeholder theory (Freeman, 1984, 1999) which are probably the most established and accepted theories of CSR in developed countries (Crane \& Matten, 2007). Based on the pyramid of CSR (Carroll, 1979, 1991), philanthropic responsibility only accounts for a small proportion of total CSR, such responsibility can be considered only when firms are serious about their economic, legal and ethical responsibility. According to stakeholder theory (Freeman, 1984, 1999), firms would encounter risk if they overemphasize one group of stakeholders while neglecting all others, such as showing massive support for the community by overinvesting in corporate philanthropy. Influenced by the CSR practices and theories of developed countries, returnee executives are more likely to regard corporate philanthropy as a minor aspect of CSR, pay more attention to the qualitative aspect of philanthropy, and consider it only when the firm has done well in other more fundamental types of CSR.

Second, returnee executives may overlook the strategic importance of corporate philanthropy in China. Executives returning to China after studying or working in developed countries face a seemingly familiar, yet different, environment. The society, culture, and institutions of China differ from those of the developed countries where they worked or studied (Li et al., 2012). In developed countries, institutional frameworks are well established and market structures are efficient (Araujo et al., 2018); thus, market strategies are preferred to nonmarket strategies such as corporate philanthropy. We expect that this preference may cause returnee executives to overlook the important role of corporate philanthropy in obtaining legitimacy in emerging economies, especially China. As the majority of registered charities are closely monitored and administrated by Chinese government departments ( $\mathrm{Li}$ et al., 2015), returnee executives may even regard donating to these charities as bribery, and thus oppose rather than support it.

To sum up, we theorize that returnee executives are likely to regard corporate philanthropy as a minor aspect of CSR and may downplay its strategic importance in obtaining legitimacy for firms in emerging economies. As firm strategies often reflect the executives' characteristics (Hambrick, 2007; Hambrick \& Mason, 1984), we propose that the proportion of returnee executives will be negatively associated with corporate philanthropy. Therefore, we propose the following hypothesis:
Hypothesis 1: The proportion of returnee executives in a firm is negatively related to corporate philanthropy.

\section{Managerial Discretion}

Based on upper echelons theory, managerial discretion is an important factor that may enable or constrain the influence of top executives on organizational outcomes (Hambrick, 2007; Hambrick \& Finkelstein, 1987). Discretion exists "when there is an absence of constraint and when there is a great deal of means-ends ambiguity - that is, when there are multiple plausible alternatives" (Hambrick, 2007: 335). Managerial discretion can affect the extent to which the executives' characteristics predict firm outcomes. When executives have more discretion, firm strategy and performance will better reflect their characteristics. If executive discretion is lacking, however, they will not exert much influence. In this paper, we focus on three indicators of managerial discretion: executive ownership, prominence, and political connections.

Ownership is an important source of power for executives (Finkelstein, 1992). When executives have larger shareholdings, they wield more power and are less likely to be restricted by the board of directors and other stakeholders (Gul et al., 2002; Morck et al., 1988). Thus, greater executive ownership would result in more managerial discretion for executives. Based on upper echelons theory, discretion strengthens executives' influence (Hambrick, 2007; Hambrick \& Finkelstein, 1987). Thus, we propose the following hypothesis:

Hypothesis 2: Executive ownership moderates the relationship between the proportion of returnee executives and corporate philanthropy, such that the relationship will be stronger when the firm has a higher level of executive ownership.

A firm's prominence reflects the degree to which external audiences are aware of its existence and view it as relevant and salient (Mishina et al., 2010; Rindova et al., 2005). Prominence can make firms more likely the target of activist attacks (Briscoe \& Safford, 2008; Edelman, 1992). Thus, prominent firms are more likely to be criticized if their charitable donations do not meet public expectations. The reactions of Chinese stakeholders to corporate contributions to COVID-19 relief exemplify this. In early 2020, Huawei, one of China's most prominent firms, donated 30 million RMB to COVID-19 relief. Although 30 million is a significant amount, the public strongly criticized Huawei's donation as inadequate. ${ }^{6}$ Thus, the increased attention that prominent

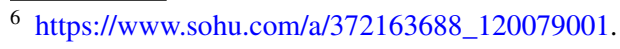


firms receive exacerbates the pressure on them to meet or exceed public expectations of corporate philanthropy. Higher prominence may therefore result in less managerial discretion regarding corporate philanthropy. Based on upper echelons theory (Hambrick, 2007; Hambrick \& Finkelstein, 1987), if managerial discretion is lacking, the relationship between the proportion of returnee executives and corporate philanthropy would be weaker. Thus, we propose:

Hypothesis 3: Prominence moderates the relationship between the proportion of returnee executives and corporate philanthropy, such that the relationship will be weaker when the firm has a high level of prominence.

Political connections can be broadly defined as the connections between firms and government agencies or officials (Li et al., 2011). The percentage of firms with political connections is greater in China than in other countries ( $\mathrm{Li}$ et al., 2015). Fan et al. (2007) found that almost $27 \%$ of CEOs in Chinese firms are former or current government bureaucrats, a significantly higher percentage than reported for Western countries. We propose that political connections may constrain managerial discretion, thereby weakening the relationship between returnee executives and corporate philanthropy for the following reasons.

Politically connected firms face more expectations regarding corporate philanthropy in China. In the absence of an efficient market and mature legal system, political allies are critical for Chinese firms to succeed in negotiating and enforcing contracts (Nee, 1992), and it has been widely observed that firms with political connections enjoy preferential government treatment (Faccio, 2010; Li et al., 2015). Because of the prevalent norm of reciprocity in China, the government may also expect more from firms with political connections (Li et al., 2015; Zhang et al., 2016). As the Chinese government relies heavily on corporate philanthropy to alleviate its resource burden (Dickson, 2003), it would expect higher philanthropic contributions from firms with political connections. These firms must strive to meet such government expectations, given the importance of government allies for the firm's operation. As such, executives in firms with political connections do not have much managerial discretion when making decisions regarding corporate philanthropy.

In addition, the Chinese government is more likely to force politically connected firms to donate more money, in China's well-known "forced donation" phenomenon (Zhang et al., 2016). Anecdotal evidence suggests that firms with political connections may receive a donation task from the government in times of need (Li et al., 2015). For example, in 2011, the government of Shenmu county in Shanxi province set up three foundations to promote social welfare. To reach the 3000 million RMB target, the Shenmu government imposed a donation task on every firm and public employee in the county. ${ }^{7}$ One of the county's politically connected firms donated as much as 450 million RMB at the time. Therefore, in China, political connections can be a binding function that facilitates donation, leaving firms with little managerial discretion regarding corporate philanthropy.

Based on upper echelons theory, when discretion is lacking, executives cannot exert much influence on firm strategy and performance (Hambrick, 2007; Hambrick \& Finkelstein, 1987). As political connections restrict managerial discretion over corporate philanthropy, we propose that the relationship between the proportion of returnee executives and corporate philanthropy would be weaker in firms with political connections.

Hypothesis 4: Political connections moderate the relationship between the proportion of returnee executives and corporate philanthropy, such that the relationship will be weaker when the firm has political connections.

\section{Methods}

\section{Sample and Data}

We tested the hypotheses using a sample of Chinese A-share listed firms from 2010 to 2017. Listed companies face stricter government monitoring and auditing than non-listed private firms in China, and must release complete and truthful statements of company governance and performance, enabling us to test the effect of returnee executives on corporate philanthropy.

We manually collected data regarding political connections and returnee executives from their biographies. The executives' biographies were obtained from CSMAR. As one of the largest databases of Chinese listed firms, CSMAR serves as the primary source of information on Chinese stock markets and the financial statements of China's listed firms (Wang \& Qian, 2011). Data on corporate philanthropy, prominence, executive ownership, and other control variables were also obtained from CSMAR. After merging all of the data and removing observations where values for key variables were missing, we obtained a final sample of 2533 firms and 12,533 firm-year observations.

\footnotetext{
$\overline{7}$ https://gongyi.qq.com/a/20110426/000064_1.htm.
} 


\section{Measures}

\section{Corporate Philanthropy}

Corporate philanthropy was assessed as the firm's total charitable contributions during a specific year. Because the variable was highly skewed, following previous studies (Adams \& Hardwick, 1998; Galaskiewicz, 1997; Wang \& Qian, 2011), we calculated its natural logarithm.

\section{Proportion of Returnee Executives}

The proportion of returnee executives was obtained by dividing the number of returnee executives by the total number of top executives. Following the prior literature (Finkelstein \& Hambrick, 1996; Kor, 2006), we defined top executives as all inside top-level executives including the chief executive officer, chief operating officer, business unit heads, and vice presidents. We identified returnee executives in the present context using the criteria of the Chinese government, which is consistent with the definition of Li et al. (2012). Specifically, we identified a returnee as a Chinese native who had studied and/or worked in an OECD country and then returned to China (Zhongguancun Science Park Management Committee, 2006). Then, for each firm, we computed the proportion of returnee executives.

\section{Moderating Variables}

Executive ownership was measured as the ratio of the firm's equity owned by top executives to total equity (Jia \& Zhang, 2013; Johnson \& Greening, 1999). We used analyst coverage of the firm as an indicator of the firm's prominence (Mishina et al., 2010), measured as the number of analysts covering the firm (Pollock \& Gulati, 2007). Following previous research on the political connections of China's listed firms (Fan et al., 2007), we used previous affiliations of the firm's CEO and chairperson with the government as an indicator of the firm's political connections. This was a dummy variable equal to 1 if the CEO or chairperson was an official of the military or the local or central government, and 0 otherwise.

\section{Control Variables}

As previous research has shown that larger firms engage in more corporate philanthropy (Amato \& Amato, 2007; Brammer \& Millington, 2006), we controlled for firm size, measured as the natural log of total assets (Tang et al., 2015). Past studies have shown that a firm's financial performance and growth may impact its CSR decisions (Waddock \& Graves, 1997); thus we controlled for firm financial performance in terms of ROA (return on assets), asset growth, and Tobin's $Q$. Following previous studies, we controlled for the debt asset ratio, measured as the ratio of long-term debt to total assets (Barnett \& Salomon, 2006; Waddock \& Graves, 1997). Our model also controlled for firm age, measured as years since establishment. As state ownership has been linked to corporate philanthropy (Gao, 2011; Muller \& Whiteman, 2009), we controlled for state ownership, measured as the ratio of stock held by the Chinese government or its agencies to the total stock (Wang et al., 2008). Past studies have also found that board composition is related to CSR (Byron \& Post, 2016; Jo \& Harjoto, 2011; Walls et al., 2012; Wang \& Dewhirst, 1992; Williams, 2003), so we controlled for board independence, female director ratio, and CEO duality. Board independence was calculated as the number of independent directors divided by board size. The female director ratio was the proportion of women directors to the total number of directors on the firm's board. CEO duality was a dummy variable coded as 1 if the CEO and board chair positions were held by the same person and 0 otherwise. We also controlled for firm philanthropic history, measured as the value of the firm's charitable contributions (logarithm transformed) in year $t-1$. To control for possible differences in corporate philanthropy across regions, we also controlled for regional philanthropy, which was measured as the average value of corporate philanthropy of the listed firms in a specific region. Furthermore, we included industry dummies based on CSMAR's industry classification, and year dummies to tease out differences as a result of time. All of the independent, moderating, and control variables were lagged by one year to predict corporate philanthropy.

\section{Results}

\section{Descriptive Statistics}

Table 1 displays the descriptive statistics and correlations for all of the variables except the industry and year dummies. To ensure that multicollinearity did not pose a problem, we calculated the variance inflation factors (VIFs) and condition index statistics (CIs), which are indicators of collinearity among predictors. All of the VIFs were less than 2.0, well below the generally accepted limit of 10.0 (Neter et al., 1996), while the mean and maximum CISs were less than 5.0 , which is well below the threshold of 30 (Belsley et al., 2005).

\section{Analysis of the Regression Results}

We first examined the relationship between the proportion of returnee executives and corporate philanthropy, and then the moderating roles of executive ownership, prominence, and political connections. The Hausman test showed that the fixed effects model is more appropriate $\left(c h i^{2}(95)=1051.44\right.$, 


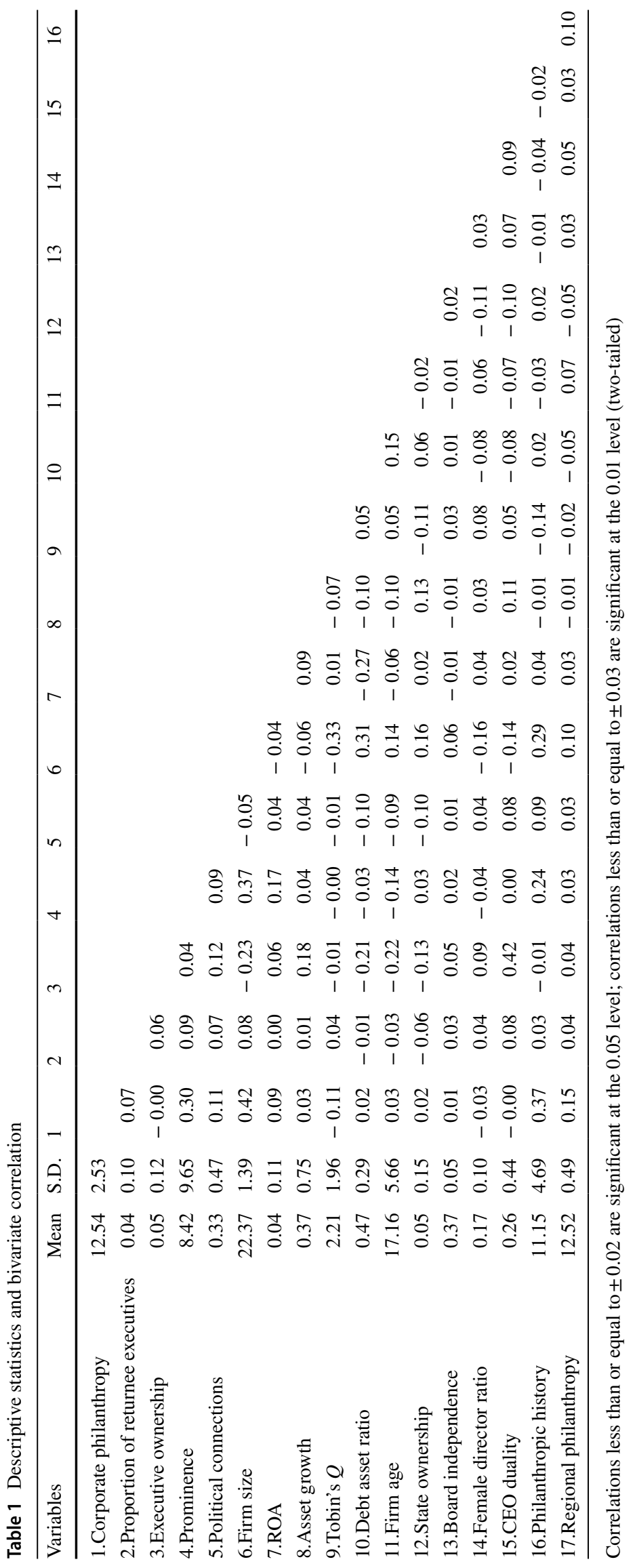


Table 2 Regression results for corporate philanthropy

\begin{tabular}{|c|c|c|c|c|c|}
\hline Variables & Model 1 & Model 2 & Model 3 & Model 4 & Model 5 \\
\hline Firm size & $\begin{array}{l}0.59 * * * \\
(0.09)\end{array}$ & $\begin{array}{l}0.60 * * * \\
(0.10)\end{array}$ & $\begin{array}{l}0.60 * * * \\
(0.09)\end{array}$ & $\begin{array}{l}0.60 * * * \\
(0.09)\end{array}$ & $\begin{array}{l}0.60 * * * \\
(0.09)\end{array}$ \\
\hline ROA & $\begin{array}{l}0.34^{+} \\
(0.18)\end{array}$ & $\begin{array}{l}0.34^{+} \\
(0.18)\end{array}$ & $\begin{array}{l}0.34^{+} \\
(0.18)\end{array}$ & $\begin{array}{l}0.34 * \\
(0.18)\end{array}$ & $\begin{array}{l}0.34^{+} \\
(0.18)\end{array}$ \\
\hline Asset growth & $\begin{array}{l}0.11 * * \\
(0.03)\end{array}$ & $\begin{array}{l}0.11^{* *} \\
(0.03)\end{array}$ & $\begin{array}{l}0.11 * * \\
(0.03)\end{array}$ & $\begin{array}{l}0.11 * * \\
(0.03)\end{array}$ & $\begin{array}{l}0.11 * * \\
(0.03)\end{array}$ \\
\hline Tobin's Q & $\begin{array}{l}0.09 * * \\
(0.02)\end{array}$ & $\begin{array}{l}0.09 * * \\
(0.02)\end{array}$ & $\begin{array}{l}0.09 * * \\
(0.02)\end{array}$ & $\begin{array}{l}0.09 * * \\
(0.02)\end{array}$ & $\begin{array}{l}0.09 * * \\
(0.02)\end{array}$ \\
\hline Debt asset ratio & $\begin{array}{l}-0.43 * * \\
(0.15)\end{array}$ & $\begin{array}{l}-0.42^{*} \\
(0.15)\end{array}$ & $\begin{array}{l}-0.42 * \\
(0.15)\end{array}$ & $\begin{array}{l}-0.42 * \\
(0.16)\end{array}$ & $\begin{array}{l}-0.42 * \\
(0.16)\end{array}$ \\
\hline Firm age & $\begin{array}{l}0.07 * * \\
(0.02)\end{array}$ & $\begin{array}{l}0.07 * * \\
(0.02)\end{array}$ & $\begin{array}{l}0.07 * * \\
(0.02)\end{array}$ & $\begin{array}{l}0.07 * * * \\
(0.02)\end{array}$ & $\begin{array}{l}0.07 * * \\
(0.02)\end{array}$ \\
\hline State ownership & $\begin{array}{l}0.42 \\
(0.26)\end{array}$ & $\begin{array}{l}0.42 \\
(0.26)\end{array}$ & $\begin{array}{l}0.42 \\
(0.26)\end{array}$ & $\begin{array}{l}0.43 \\
(0.26)\end{array}$ & $\begin{array}{l}0.43 \\
(0.26)\end{array}$ \\
\hline Board independence & $\begin{array}{l}-0.25 \\
(0.57)\end{array}$ & $\begin{array}{l}-0.21 \\
(0.57)\end{array}$ & $\begin{array}{l}-0.23 \\
(0.58)\end{array}$ & $\begin{array}{l}-0.24 \\
(0.58)\end{array}$ & $\begin{array}{l}-0.23 \\
(0.57)\end{array}$ \\
\hline Female director ratio & $\begin{array}{l}0.70^{+} \\
(0.35)\end{array}$ & $\begin{array}{l}0.70^{+} \\
(0.35)\end{array}$ & $\begin{array}{l}0.70^{*} \\
(0.34)\end{array}$ & $\begin{array}{l}0.68^{+} \\
(0.34)\end{array}$ & $\begin{array}{l}0.70^{*} \\
(0.34)\end{array}$ \\
\hline CEO duality & $\begin{array}{l}0.03 \\
(0.05)\end{array}$ & $\begin{array}{l}0.03 \\
(0.05)\end{array}$ & $\begin{array}{l}0.03 \\
(0.05)\end{array}$ & $\begin{array}{l}0.03 \\
(0.05)\end{array}$ & $\begin{array}{l}0.03 \\
(0.05)\end{array}$ \\
\hline Philanthropic history & $\begin{array}{l}-0.03^{* * *} \\
(0.01)\end{array}$ & $\begin{array}{l}-0.03 * * * \\
(0.01)\end{array}$ & $\begin{array}{l}-0.03^{* * *} \\
(0.01)\end{array}$ & $\begin{array}{l}-0.03 * * * \\
(0.01)\end{array}$ & $\begin{array}{l}-0.03 * * * \\
(0.01)\end{array}$ \\
\hline Regional philanthropy & $\begin{array}{l}0.16^{+} \\
(0.08)\end{array}$ & $\begin{array}{l}0.16^{+} \\
(0.08)\end{array}$ & $\begin{array}{l}0.16^{+} \\
(0.08)\end{array}$ & $\begin{array}{l}0.16^{+} \\
(0.08)\end{array}$ & $\begin{array}{l}0.16^{*} \\
(0.08)\end{array}$ \\
\hline Executive ownership & $\begin{array}{l}1.10^{* * *} \\
(0.36)\end{array}$ & $\begin{array}{l}1.08 * * \\
(0.36)\end{array}$ & $\begin{array}{l}1.08 * * \\
(0.36)\end{array}$ & $\begin{array}{l}1.08 * * \\
(0.37)\end{array}$ & $\begin{array}{l}1.05^{* *} \\
(0.37)\end{array}$ \\
\hline Prominence & $\begin{array}{l}0.01 * * \\
(0.00)\end{array}$ & $\begin{array}{l}0.01 * * \\
(0.00)\end{array}$ & $\begin{array}{l}0.01 * * \\
(0.00)\end{array}$ & $\begin{array}{l}0.01 * * \\
(0.00)\end{array}$ & $\begin{array}{l}0.01 * * \\
(0.00)\end{array}$ \\
\hline Political connections & $\begin{array}{l}0.12 \\
(0.15)\end{array}$ & $\begin{array}{l}0.13 \\
(0.15)\end{array}$ & $\begin{array}{l}0.13 \\
(0.15)\end{array}$ & $\begin{array}{l}0.13 \\
(0.15)\end{array}$ & $\begin{array}{l}0.13 \\
(0.16)\end{array}$ \\
\hline Proportion of returnee executives & & $\begin{array}{l}-0.58^{*} \\
(0.26)\end{array}$ & $\begin{array}{l}-0.63^{*} \\
(0.26)\end{array}$ & $\begin{array}{l}-0.75^{*} \\
(0.29)\end{array}$ & $\begin{array}{l}-0.79 * * \\
(0.28)\end{array}$ \\
\hline $\begin{array}{l}\text { Proportion of returnee executives } \\
\times \text { Executive ownership }\end{array}$ & & & $\begin{array}{l}-0.04 * \\
(0.02)\end{array}$ & $\begin{array}{l}-0.04^{+} \\
(0.02)\end{array}$ & $\begin{array}{l}-0.06^{* *} \\
(0.02)\end{array}$ \\
\hline $\begin{array}{l}\text { Proportion of returnee executives } \\
\times \text { Prominence }\end{array}$ & & & & $\begin{array}{l}0.04 * \\
(0.02)\end{array}$ & $\begin{array}{l}0.04^{*} \\
(0.02)\end{array}$ \\
\hline $\begin{array}{l}\text { Proportion of returnee execu- } \\
\text { tives } \times \text { Political connections }\end{array}$ & & & & & $\begin{array}{l}0.10 * * * \\
(0.02)\end{array}$ \\
\hline Industry dummies & Included & Included & Included & Included & Included \\
\hline Year dummies & Included & Included & Included & Included & Included \\
\hline$R^{2}$ & 0.09 & 0.09 & 0.09 & 0.09 & 0.09 \\
\hline$N$ & 12,533 & 12,533 & 12,533 & 12,533 & 12,533 \\
\hline
\end{tabular}

Standard errors in parentheses

${ }^{+} p<0.1, * p<0.05, * * p<0.01, * * * p<0.001$, two - tailed tests $p<0.001$ ), so the fixed effects model was used to run the regression tests (Wooldridge, 2003). The fixed-effects model, which mainly focuses on within-group variance (Wooldridge, 2003), enabled us to examine the relationship between the proportion of returnee executives in a firm and its corporate philanthropy.

Table 2 presents the results of the fixed effects analysis. Model 1 reports the effects of the basic firm-level control variables. In Model 2, we added the proportion of returnee 
Fig. 2 Moderating effect of executive ownership on the relationship between the proportion of returnee executives and corporate philanthropy

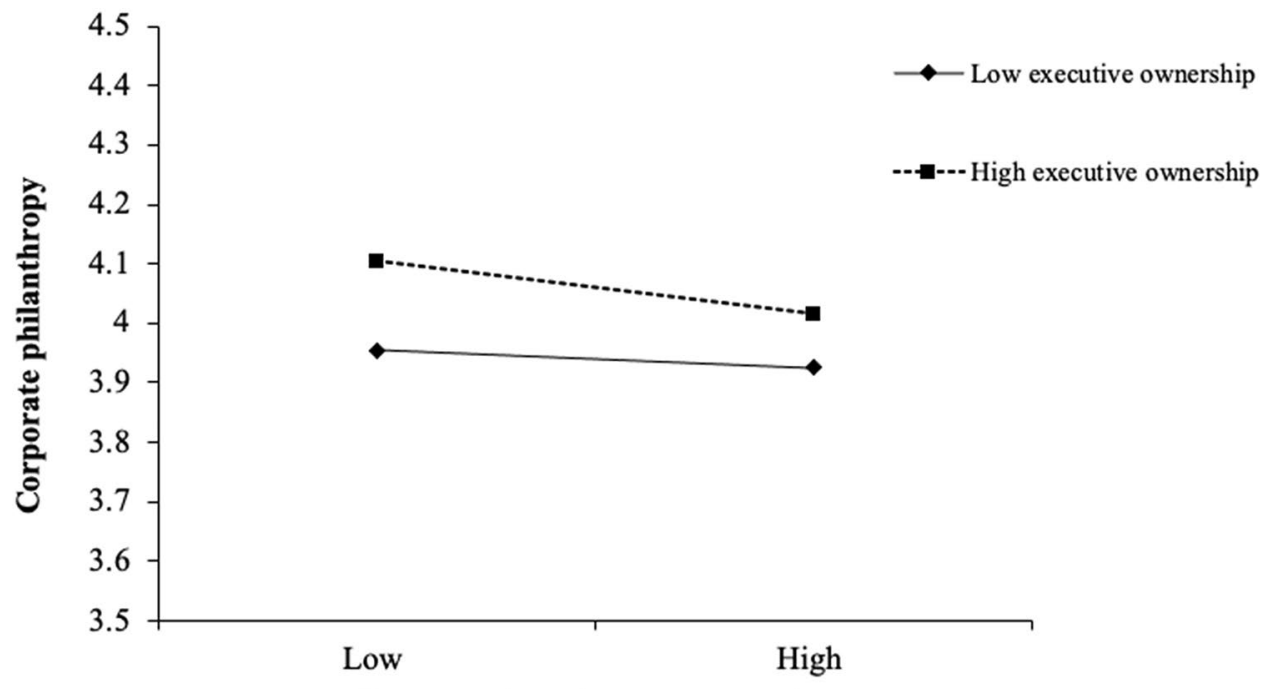

The proportion of returnee executives

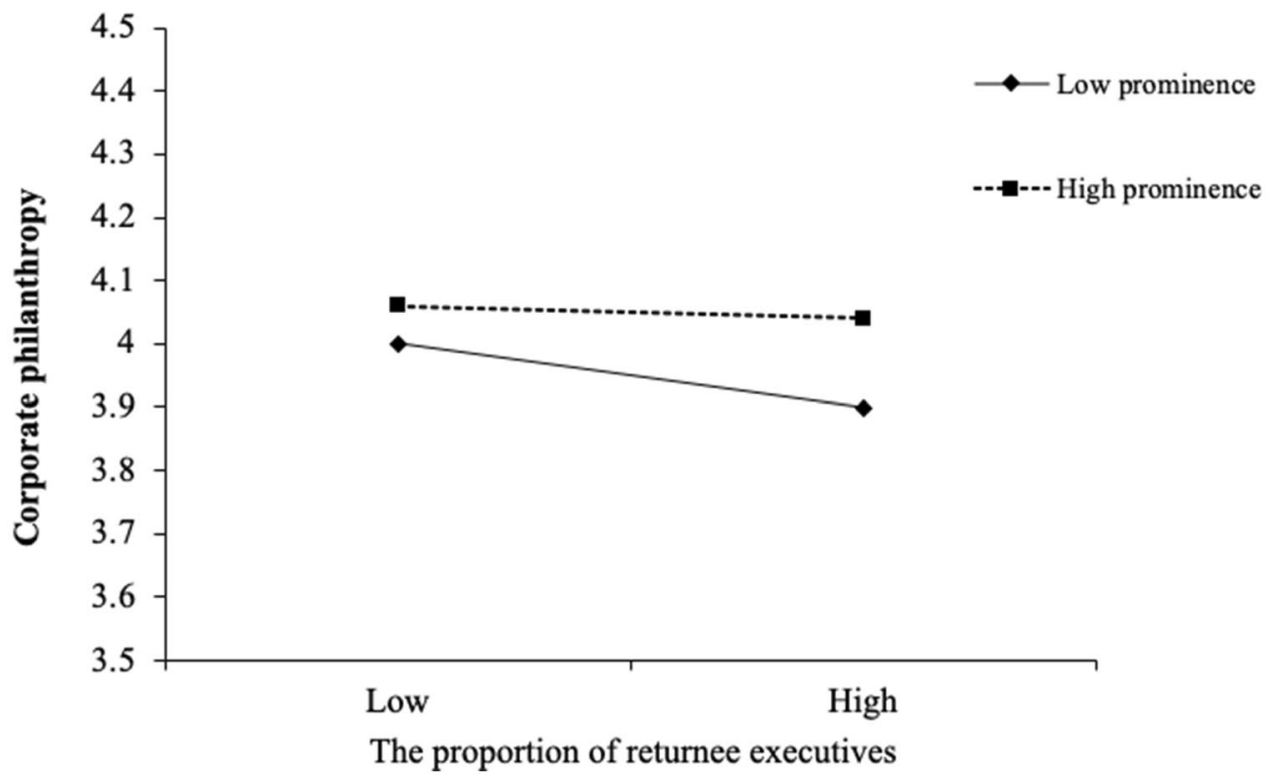

Fig. 3 Moderating effect of prominence on the relationship between the proportion of returnee executives and corporate philanthropy executives. The negative and statistically significant coefficient $(\beta=-0.58, p<0.05)$ suggests that the proportion of returnee executives is negatively related to corporate philanthropy, providing support for Hypothesis 1.

Hypothesis 2 posits that executive ownership moderates the relationship between the proportion of returnee executives and corporate philanthropy. As Model 3 shows, the coefficient of the interaction term between executive ownership and the proportion of returnee executives is negative and statistically significant $(\beta=-0.04, p<0.05)$, indicating that the relationship between the proportion of returnee executives and corporate philanthropy is strengthened by executive ownership. To gain more insight into this interaction effect, we plotted the relationships in Fig. 2 (Aiken \&
West, 1991). Figure 2 shows that relationship between the proportion of returnee executives and corporate philanthropy is negative but not significant when the firm has low executive ownership (simple slope $b=-0.25$, n.s.), but becomes significantly negative when the firm has high executive ownership (simple slope $b=-1.01, p<0.05$ ). These results strongly support Hypothesis 2.

Hypothesis 3 predicts that firm prominence moderates the relationship between the proportion of returnee executives and corporate philanthropy. Model 4 shows that the coefficient of the interaction between prominence and the proportion of returnee executives is positive and statistically significant $(\beta=0.04, p<0.05)$, indicating that the relationship between the proportion of returnee executives and corporate 
Fig. 4 Moderating effect of political connections on the relationship between the proportion of returnee executives and corporate philanthropy

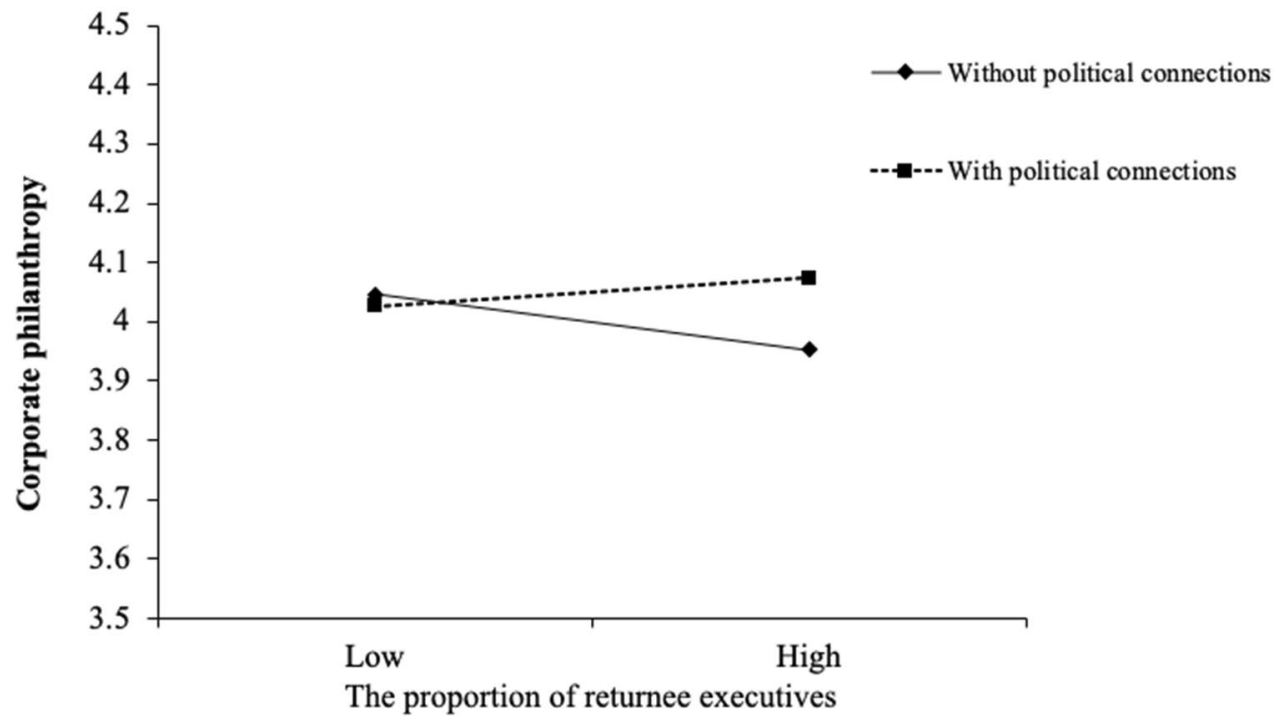

philanthropy is weakened by corporate prominence. As shown in Fig. 3, the relationship between the proportion of returnee executives and corporate philanthropy is significantly negative when the firm has low prominence (simple slope $b=-1.14, p<0.05$ ), but becomes non-significant when the firm has high prominence (simple slope $b=-0.36$, n.s.). These results strongly support Hypothesis 3 .

Model 5 tests Hypothesis 4, which predicts that the relationship between the proportion of returnee executives and corporate philanthropy is weaker when the firm has political connections than when it does not. Model 4 shows that political connections weaken the negative relationship between the proportion of returnee executives and corporate philanthropy $(\beta=0.10, p<0.001)$. As shown in Fig. 4, the relationship between the proportion of returnee executives and corporate philanthropy is negative and statistically significant when the firm lacks political connections (simple slope $b=-1.07, p<0.01$ ), while it is not significant when the firm has political connections (simple slope $b=0.53$, n.s.). Therefore, $\mathrm{H} 4$ is also strongly supported.

\section{Robustness Checks}

To check the robustness of our findings, we conducted two tests. First, to verify our findings for the moderators, we conducted regression tests by splitting the sample. To test Hypothesis 2, we divided the sample into two subsamples by executive ownership, using a median split to categorize the two groups (Yiu et al., 2014). The result shows that the relationship between the proportion of returnee executives and corporate philanthropy is not significantly in firms with low executive ownership $(\beta=-0.07, n . s$.$) , but is significantly$ negative $(\beta=-0.75, p<0.05)$ when executive ownership is high. Similarly, we divided the sample into two subsamples by corporate prominence to test Hypothesis 3. The results show that the relationship between the proportion of returnee executives and corporate philanthropy is significantly negative $(\beta=-0.78, p<0.05)$ for the subsample of firms with low prominence, but is not significant for firms with high prominence $(\beta=-0.04$, n.s. $)$. We tested Hypothesis 4 by dividing the sample into two subsamples based on political connections. The result shows that the relationship between the proportion of returnee executives and corporate philanthropy is significantly negative $(\beta=-1.22, p<0.01)$ for firms without political connections, but is not significant for firms with political connections $(\beta=-0.12$, n.s.). To sum up, the results are consistent with those of our main analysis.

Second, as the proportion of returnee executives could be endogenous to corporate philanthropy due to simultaneous or reverse causality, following past studies (Giannetti et al., 2015), we used the instrumental variable method to address these endogeneity concerns. The appropriate use of instrumental variables requires instruments that satisfy two conditions: strength (i.e. the instruments should be able to explain the proportion of returnee executives) and endogeneity (i.e. the instruments should not explain corporate philanthropy) (Giannetti et al., 2015). We chose overseas listing and foreign ownership as instrumental variables. Overseas listing was a dummy variable coded as 1 if the firm was also listed abroad, and 0 otherwise. Foreign ownership was measured as the ratio of stock held by foreign institutional investors or foreign corporate investors to total stock. On the one hand, firms overseas-listed or with high foreign ownership are more likely to attract and hire returnee executives, thus these two factors satisfy the condition of strength. On the other hand, overseas listing and foreign ownership are less likely to be related to corporate philanthropy. In the Chinese listed firms that are also listed overseas or with foreign ownership, foreign investors are often dispersed, minority shareholders, and thus have limited impact on firms' behaviors and 
Table 3 Regression results for corporate philanthropy with instrumental variable

\begin{tabular}{|c|c|c|}
\hline Variables & $\begin{array}{l}\text { First stage } \\
\text { Proportion of } \\
\text { returnee execu- } \\
\text { tives }\end{array}$ & $\begin{array}{l}\text { Second } \\
\text { stage } \\
\text { Corporate } \\
\text { philan- } \\
\text { thropy }\end{array}$ \\
\hline Firm size & $\begin{array}{l}0.01 * * * \\
(0.00)\end{array}$ & $\begin{array}{l}0.66 * * * \\
(0.06)\end{array}$ \\
\hline ROA & $\begin{array}{l}0.01 \\
(0.00)\end{array}$ & $\begin{array}{l}0.37 * \\
(0.17)\end{array}$ \\
\hline Asset growth & $\begin{array}{l}-0.00 \\
(0.00)\end{array}$ & $\begin{array}{l}0.11 * * * \\
(0.03)\end{array}$ \\
\hline Tobin's Q & $\begin{array}{l}0.00 * * \\
(0.00)\end{array}$ & $\begin{array}{l}0.10 * * * \\
(0.02)\end{array}$ \\
\hline Debt asset ratio & $\begin{array}{l}0.01 * \\
(0.00)\end{array}$ & $\begin{array}{l}-0.38 * * * \\
(0.10)\end{array}$ \\
\hline Firm age & $\begin{array}{l}0.00^{+} \\
(0.00)\end{array}$ & $\begin{array}{l}0.08 * * * \\
(0.01)\end{array}$ \\
\hline State ownership & $\begin{array}{l}0.00 \\
(0.00)\end{array}$ & $\begin{array}{l}0.43^{*} \\
(0.17)\end{array}$ \\
\hline Board independence & $\begin{array}{l}0.06 * * * \\
(0.02)\end{array}$ & $\begin{array}{l}0.14 \\
(0.62)\end{array}$ \\
\hline Female director ratio & $\begin{array}{l}0.01 \\
(0.01)\end{array}$ & $\begin{array}{l}0.74 * \\
(0.36)\end{array}$ \\
\hline CEO duality & $\begin{array}{l}-0.00 \\
(0.00)\end{array}$ & $\begin{array}{l}0.01 \\
(0.07)\end{array}$ \\
\hline Philanthropic history & $\begin{array}{l}-0.00 * \\
(0.00)\end{array}$ & $\begin{array}{l}-0.03 * * * \\
(0.00)\end{array}$ \\
\hline Regional philanthropy & $\begin{array}{l}-0.00 \\
(0.00)\end{array}$ & $\begin{array}{l}0.15^{* *} \\
(0.06)\end{array}$ \\
\hline Executive ownership & $\begin{array}{l}-0.04 * * * \\
(0.01)\end{array}$ & $\begin{array}{l}0.85^{*} \\
(0.37)\end{array}$ \\
\hline Prominence & $\begin{array}{l}0.00 \\
(0.00)\end{array}$ & $\begin{array}{l}0.01 * * * \\
(0.00)\end{array}$ \\
\hline Political connections & $\begin{array}{l}0.00 \\
(0.00)\end{array}$ & $\begin{array}{l}0.14 \\
(0.09)\end{array}$ \\
\hline Overseas listing & $\begin{array}{l}0.11 * * * \\
(0.01)\end{array}$ & \\
\hline Foreign ownership & $\begin{array}{l}0.04 * * \\
(0.01)\end{array}$ & \\
\hline Proportion of returnee executives & & $\begin{array}{l}-6.27 * \\
(3.01)\end{array}$ \\
\hline Industry dummies & Included & Included \\
\hline Year dummies & Included & Included \\
\hline$R^{2}$ & 0.06 & 0.07 \\
\hline$N$ & 12,533 & 12,533 \\
\hline
\end{tabular}

Standard errors in parentheses

${ }^{+} p<0.1, * p<0.05, * * p<0.01, * * * p<0.001$, two-tailed tests outcomes (Tam et al., 2010). Moreover, the main incentives of foreign investors are making money and building business opportunities with the Chinese government, rather than promoting CSR (Fergusson \& Mcguinness, 2004). In this regard, CSR-engagement such as corporate philanthropy is not the priority for them. The above arguments are supported by some empirical evidences. For example, using a sample of Chinese listed firms, McGuinness et al. (2017) found that overseas listing and foreign ownership are not related to CSR. Lin et al. (2018) find that the proportion of stock owned by foreign institutional investors is not associated with corporate philanthropy. Therefore, these two factors satisfy the condition of endogeneity.

Table 3 reports the empirical results of the two-stage instrumental variable analysis. Column 1 reports the results of the first-stage regression, in which the proportion of returnee executives is predicted by the two instrumental variables and other control variables. The result shows that the coefficients of overseas listing $(\beta=0.11, p<0.001)$ and foreign ownership $(\beta=0.04, p<0.01)$ are significant and positive. This suggests that overseas-listed firms and firms with a high level of foreign capital are more likely to hire returnee executives. The Cragg-Donald Wald $F$-statistic $(F=68.95)$ for the weak identification test (Cragg \& Donald, 1993) rejects the null hypotheses and confirms that both instrumental variables are strong instrumental variables, which means that both instrumental variables are relevant predictors of the proportion of returnee executives. The Sargan statistic $\left(\chi^{2}(1)=2.47\right)$ for the overidentification test cannot reject the null hypothesis that the instruments are uncorrelated with the error term, suggesting that the instruments can not explain corporate philanthropy. The identification tests above show that the instruments used are valid. Column 2 reports the second-stage regression results. The results show that the coefficient of the proportion of returnee executives is still negative and significant $(\beta=-6.27, p<0.05)$. Therefore, the finding supporting $\mathrm{H} 1$ remains robust after addressing endogeneity concerns.

\section{Post Hoc Analysis}

Based on our main analysis, we found that the proportion of returnee executives is negatively related to corporate philanthropy. To explore whether this relationship is caused by the executives' overseas education or their overseas work experience, we conducted a supplementary analysis. Specifically, overseas work experience was obtained by dividing the number of returnee executives who previously worked abroad by the number of top executives. Overseas education was measured as the proportion of returnee executives educated abroad. As the results show, overseas education is negatively related to corporate philanthropy $(\beta=-1.29$, 
Table 4 Regression results for overall CSR

\begin{tabular}{|c|c|c|}
\hline & Model 1 & Model 2 \\
\hline \multirow[t]{2}{*}{ Firm size } & $1.72 * * *$ & $1.66 * * *$ \\
\hline & $(0.36)$ & $(0.36)$ \\
\hline \multirow[t]{2}{*}{ ROA } & $2.77 *$ & $2.73^{*}$ \\
\hline & $(1.25)$ & $(1.25)$ \\
\hline \multirow[t]{2}{*}{ Asset growth } & 0.14 & 0.15 \\
\hline & $(0.20)$ & $(0.20)$ \\
\hline \multirow[t]{2}{*}{ Tobin's $Q$} & $0.59 * * *$ & $0.58 * * *$ \\
\hline & $(0.12)$ & $(0.12)$ \\
\hline \multirow[t]{2}{*}{ Debt asset ratio } & $-2.25 * *$ & $-2.30 * *$ \\
\hline & $(0.72)$ & $(0.72)$ \\
\hline \multirow[t]{2}{*}{ Firm age } & $-1.89 * * *$ & $-1.90 * * *$ \\
\hline & $(0.09)$ & $(0.09)$ \\
\hline \multirow[t]{2}{*}{ State ownership } & $6.82 * * *$ & $6.80 * * *$ \\
\hline & $(1.24)$ & $(1.24)$ \\
\hline \multirow[t]{2}{*}{ Board independence } & $7.55^{+}$ & $7.19^{+}$ \\
\hline & $(4.31)$ & $(4.31)$ \\
\hline \multirow[t]{2}{*}{ Female director ratio } & -1.88 & -1.92 \\
\hline & $(2.60)$ & $(2.60)$ \\
\hline \multirow[t]{2}{*}{ CEO duality } & -0.14 & -0.12 \\
\hline & $(0.49)$ & $(0.49)$ \\
\hline \multirow[t]{2}{*}{ Executive ownership } & -2.36 & -2.11 \\
\hline & $(2.56)$ & $(2.56)$ \\
\hline \multirow[t]{2}{*}{ Prominence } & $0.28 * * *$ & $0.28 * * *$ \\
\hline & $(0.02)$ & $(0.02)$ \\
\hline \multirow[t]{2}{*}{ Political connections } & -0.08 & -0.09 \\
\hline & $(0.68)$ & $(0.68)$ \\
\hline \multirow[t]{2}{*}{ Proportion of returnee executives } & & $5.86^{*}$ \\
\hline & & $(2.55)$ \\
\hline Industry dummies & Included & Included \\
\hline Year dummies & Included & Included \\
\hline$R^{2}$ & 0.21 & 0.21 \\
\hline$N$ & 12,533 & 12,533 \\
\hline
\end{tabular}

Standard errors in parentheses

${ }^{+} p<0.1, * p<0.05, * * p<0.01, * * * p<0.001$, two-tailed tests

$p<0.05)$, while overseas work experience is not significantly related to corporate philanthropy $(\beta=-0.25, n . s$. $)$.

We reason that returnee executives are deeply influenced by the comprehensive CSR view and may overlook the strategic importance of corporate philanthropy in emerging economies in China. To gain more insight into returnee executives' views on CSR, we further examined the relationship between the proportion of returnee executives and overall CSR. We obtained data on CSR from the Hexun social responsibility score, one of the major sources for grading the CSR engagement of Chinese firms (Gong et al., 2021; Zhong et al., 2019). Similar to the KLD, the Hexun social responsibility score is a comprehensive score based on the firm's self-disclosed CSR report and annual reports. The score covers five aspects: shareholder responsibility, employee responsibility, supply chain responsibility, environmental responsibility, and public welfare responsibility. The five indicators have 13 secondary indicators and 37 tertiary indicators (Gong et al., 2021; Zhong et al., 2019). For example, the evaluation of public welfare responsibility is based on tax and corporate philanthropy. The overall CSR score is a weighted sum of the five indicators, with a maximum possible score of 100. A higher Hexun social responsibility score indicates greater overall CSR. Table 4 presents the results of the regression analysis for the relationship between the proportion of returnee executives and overall CSR. Model 1 is the baseline model with only control variables. Model 2 shows that the relationship between the proportion of returnee executives and overall CSR is positive and statistically significant $(\beta=5.86, p<0.05)$. The result is in line with the comprehensive CSR view in the literature (Han et al., 2019; Zhang et al., 2018). Table 5 presents the results of the regression analysis of the relationship between the proportion of returnee executives and various CSR components. As Table 5 shows, the proportion of returnee executives is positively related to firm's social responsibility toward its stockholders and employees, but is not related to firm's social responsibility toward its supply chain, the environment, or public welfare. The findings indicate that returnee executives may pay more attention to internal than external stakeholders. These results indicate that returnee executives' views regarding CSR are consistent with CSR practices in developed countries.

\section{Discussion and Conclusion}

In this study, we adopt upper echelons theory as our overarching perspective to investigate the relationship between returnee executives and corporate philanthropy. We propose that the proportion of returnee executives is negatively related to corporate philanthropy. Using the sample of Chinese listed companies from 2010 to 2017, we find that when firms have a higher proportion of returnee executives, they tend to engage less in corporate philanthropy. This indicates that returnee executives may downplay the importance of corporate philanthropy as a nonmarket strategy in China. This could limit the effectiveness of returnees, because in emerging economies where market structures are not well developed, a nonmarket strategy is crucial for doing businesses (Mellahi et al., 2016).

Our results also reveal that the relationship between the proportion of returnee executives and corporate philanthropy is strengthened by executive ownership but weakened by corporate prominence and political connections. Our findings suggest that corporate prominence and political 
Table 5 Regression results for different components of CSR

\begin{tabular}{|c|c|c|c|c|c|}
\hline Variables & Stockholder & Employee & Supply chain & Environment & Public welfare \\
\hline Firm size & $\begin{array}{l}-0.51 * \\
(0.25)\end{array}$ & $\begin{array}{l}0.62 * * * \\
(0.11)\end{array}$ & $\begin{array}{l}0.66^{* * * *} \\
(0.15)\end{array}$ & $\begin{array}{l}0.89 * * * \\
(0.16)\end{array}$ & $\begin{array}{l}-0.03 \\
(0.11)\end{array}$ \\
\hline ROA & $\begin{array}{l}2.48^{*} \\
(0.95)\end{array}$ & $\begin{array}{l}0.20 \\
(0.18)\end{array}$ & $\begin{array}{l}0.16 \\
(0.21)\end{array}$ & $\begin{array}{l}0.09 \\
(0.24)\end{array}$ & $\begin{array}{l}-0.14 \\
(0.17)\end{array}$ \\
\hline Asset growth & $\begin{array}{l}0.73 * * * \\
(0.07)\end{array}$ & $\begin{array}{l}-0.15^{* *} \\
(0.04)\end{array}$ & $\begin{array}{l}-0.20^{* *} \\
(0.05)\end{array}$ & $\begin{array}{l}-0.28 * * * \\
(0.06)\end{array}$ & $\begin{array}{l}0.06 \\
(0.04)\end{array}$ \\
\hline Tobin's $Q$ & $\begin{array}{l}0.16^{* * *} \\
(0.05)\end{array}$ & $\begin{array}{l}0.11 * * * \\
(0.03)\end{array}$ & $\begin{array}{l}0.14 * * \\
(0.04)\end{array}$ & $\begin{array}{l}0.15^{* * *} \\
(0.03)\end{array}$ & $\begin{array}{l}0.01 \\
(0.04)\end{array}$ \\
\hline Debt asset ratio & $\begin{array}{l}-1.03 * * \\
(0.34)\end{array}$ & $\begin{array}{l}-0.14 \\
(0.14)\end{array}$ & $\begin{array}{l}-0.30 * \\
(0.14)\end{array}$ & $\begin{array}{l}-0.22 \\
(0.15)\end{array}$ & $\begin{array}{l}-0.56^{* * *} \\
(0.13)\end{array}$ \\
\hline Firm age & $\begin{array}{l}0.04 \\
(0.05)\end{array}$ & $\begin{array}{l}-0.38 * * * \\
(0.05)\end{array}$ & $\begin{array}{l}-0.66^{* * * *} \\
(0.07)\end{array}$ & $\begin{array}{l}-0.71 * * * \\
(0.07)\end{array}$ & $\begin{array}{l}-0.19^{* * *} \\
(0.03)\end{array}$ \\
\hline State ownership & $\begin{array}{l}1.45^{*} \\
(0.65)\end{array}$ & $\begin{array}{l}1.34 * * \\
(0.38)\end{array}$ & $\begin{array}{l}1.58 * * \\
(0.47)\end{array}$ & $\begin{array}{l}1.86^{* *} \\
(0.63)\end{array}$ & $\begin{array}{l}0.45 \\
(0.45)\end{array}$ \\
\hline Board independence & $\begin{array}{l}1.34 \\
(1.48)\end{array}$ & $\begin{array}{l}1.49 \\
(0.89)\end{array}$ & $\begin{array}{l}1.54 \\
(1.66)\end{array}$ & $\begin{array}{l}1.00 \\
(1.61)\end{array}$ & $\begin{array}{l}2.68^{*} \\
(0.99)\end{array}$ \\
\hline Female director ratio & $\begin{array}{l}-0.94 \\
(0.97)\end{array}$ & $\begin{array}{l}0.07 \\
(0.63)\end{array}$ & $\begin{array}{l}-0.53 \\
(0.83)\end{array}$ & $\begin{array}{l}-0.07 \\
(0.75)\end{array}$ & $\begin{array}{l}-1.03 \\
(0.79)\end{array}$ \\
\hline CEO duality & $\begin{array}{l}0.10 \\
(0.17)\end{array}$ & $\begin{array}{l}-0.01 \\
(0.11)\end{array}$ & $\begin{array}{l}-0.08 \\
(0.21)\end{array}$ & $\begin{array}{l}-0.04 \\
(0.21)\end{array}$ & $\begin{array}{l}-0.05 \\
(0.14)\end{array}$ \\
\hline Executive ownership & $\begin{array}{l}4.08 * * \\
(1.19)\end{array}$ & $\begin{array}{l}-1.59 * * \\
(0.54)\end{array}$ & $\begin{array}{l}-1.96 * \\
(0.79)\end{array}$ & $\begin{array}{l}-1.89 * \\
(0.89)\end{array}$ & $\begin{array}{l}-1.15 \\
(0.72)\end{array}$ \\
\hline Prominence & $\begin{array}{l}0.12 * * * \\
(0.01)\end{array}$ & $\begin{array}{l}0.03 * * * \\
(0.01)\end{array}$ & $\begin{array}{l}0.05 * * * \\
(0.01)\end{array}$ & $\begin{array}{l}0.06 * * * \\
(0.01)\end{array}$ & $\begin{array}{l}0.03 * * * \\
(0.01)\end{array}$ \\
\hline Political connections & $\begin{array}{l}0.33 \\
(0.24)\end{array}$ & $\begin{array}{l}0.03 \\
(0.12)\end{array}$ & $\begin{array}{l}-0.13 \\
(0.27)\end{array}$ & $\begin{array}{l}-0.15 \\
(0.22)\end{array}$ & $\begin{array}{l}-0.03 \\
(0.18)\end{array}$ \\
\hline Proportion of returnee executives & $\begin{array}{l}1.61 * \\
(0.77)\end{array}$ & $\begin{array}{l}1.17 * \\
(0.55)\end{array}$ & $\begin{array}{l}-0.18 \\
(1.16)\end{array}$ & $\begin{array}{l}-0.02 \\
(1.12)\end{array}$ & $\begin{array}{l}-0.33 \\
(0.76)\end{array}$ \\
\hline Industry dummies & Included & Included & Included & Included & Included \\
\hline Year dummies & Included & Included & Included & Included & Included \\
\hline$R^{2}$ & 0.09 & 0.19 & 0.20 & 0.20 & 0.04 \\
\hline$N$ & 12,533 & 12,533 & 12,533 & 12,533 & 12,533 \\
\hline
\end{tabular}

Standard errors in parentheses

${ }^{*} p<0.05, * * p<0.01, * * * p<0.001$, two-tailed tests connections may reduce the disadvantage of returnee executives overlooking the importance of corporate philanthropy.

Post hoc analysis show that the relationship between overseas education and corporate philanthropy is significantly negative, while the relationship between overseas work experience and corporate philanthropy is not significant. The reason may be that most of the returnee executives were young when they studied abroad, at an age when they could be more easily swayed by new views and practices in the developed countries, such as comprehensive CSR. Such findings are consistent with the literature on acculturation, which claims that adolescence is a critical period in the process of acculturation (Nagao, 1998). Our results suggest that, compared to executives with overseas work experience, those with overseas education experience are better agents for transposing institutions from foreign countries to their home country.

In addition, our results show that the proportion of returnee executives is positively related to overall CSR, which is consistent with prior studies (Han et al., 2019; Zhang et al., 2018). Interestingly, although corporate philanthropy is one aspect of CSR, returnee executives may affect corporate philanthropy and overall CSR differently. Such findings highlight returnee executives as institutional agents of CSR. By transposing comprehensive CSR view from developed countries to home country, returnee executives promote CSR practice in home country. Our study is consistent with the literature on institutional transposition which posits that migration is a source of institutional 
transposition, with people moving from one country to another carrying ideas across borders (Campbell, 2004).

\section{Contributions and Implications}

This study has several important theoretical implications. First, we contribute to the of strategic leadership literature, particularly returnee executives, by exploring the relationship between executive characteristics and firm nonmarket strategy. While prior studies dominantly focused the impact of top leaders on firm-level outcomes and market strategy (e.g., Filatotchev et al., 2009; Lin et al., 2014; Souitaris \& Maestro, 2010), our findings about the relationship between returnee executives and corporate philanthropy enriches our understanding of how executives' international experience influences firm nonmarket strategies. Moreover, given the importance of nonmarket strategies such as corporate philanthropy for firms in emerging economies (Mellahi et al., 2016), our finding that returnee executives may overlook the strategic importance of corporate philanthropy in China provides evidence for the negative view of returnees, which is relatively underexamined in the literature.

Second, we contribute to the literature on corporate philanthropy in particular, and CSR in general, by highlighting corporate philanthropy as an important nonmarket strategy in emerging economies that differs from other components of CSR. Although prior studies have explored the effect of returnee executives on the overall CSR (Bertrand et al., 2021; Han et al., 2019; Zhang et al., 2018), little is so far known about whether this logic can be applied to corporate philanthropy. Despite being a dimension of CSR, corporate philanthropy has unique attributes and more strategic implications than other components of CSR (Li et al., 2015; Wang \& Qian, 2011), thus is worthy of independent scrutiny (Wang et al., 2016). Our findings indicate that returnee executives influence corporate philanthropy and overall CSR in opposite ways, suggesting that they may overlook the strategic importance of corporate philanthropy in obtaining legitimacy while overestimating the value of other aspects of CSR. In this way, our study extends our understanding of the relationship between returnee executives and CSR and highlights the differences between corporate philanthropy and other components of CSR.

Third, we contribute to upper echelons theory in two ways. Different from the view focusing on the impact of individual executives (Liu et al., 2021; Zhang et al., 2020), our findings about the relationship between top executives' overseas experience and corporate philanthropy indicate that the demographic heterogeneity of top executives has strong explanations for firm strategic choices. Thus, it provides evidence for the view on upper echelon theory that advocates the examination of the collective attributes of executives rather than individual executives (Beckman \& Burton, 2011; Hambrick, 2007). In addition, although many studies have examined managerial discretion and its impact, most have been set in the Western context (e.g., Finkelstein \& Hambrick, 1990); little is known about the factors enabling or restricting managerial discretion in emerging economies. The context of corporate philanthropy in China offers an opportunity to discover additional discretion-related factors that are deeply embedded in this particular context, such as political connections. Therefore, our findings provide new insights into the role and scope of executive discretion in firm nonmarket strategies in emerging economies.

In addition to theoretical contributions, our findings have practical implications for firms and regulators. First, our findings suggest that returnee executives may overlook the strategic importance of corporate philanthropy in obtaining legitimacy in China, which may bring negative consequences for the firm, such as a loss of legitimacy. Thus, firms with a higher proportion of returnee executives should be aware of this risk and take measures to overcome it. For example, firms could use systematic training programs to enhance returnee executives' understanding of the institutional environment and nonmarket strategies in China. Second, our study shed light on the advantage of reverse migrant policies from the perspective of CSR. Since the late 1990s, Chinese government has adopted various policies to attract distinguished Chinese expatriates by offering them preferential and generous benefits. In response to such polices, a large number of Chinese expatriates came back to China. Many of them served as executives of China's listed firms after returning. Our study shows that although such returnee executives may overlook corporate philanthropy, they tend to promote CSR in general, thus promoting social welfare in the long run. More importantly, they can transpose comprehensive CSR view from developed countries to China and promote the development of CSR practice in China. Therefore, to ensure sustainable business development, governments in emerging economies should issue more preferential policies to attract expatriates (particularly those with foreign education experience) to listed firms in their countries.

\section{Limitations and Future Directions}

Despite its notable contributions, this study is not without limitations. First, returnee executives in different countries may have different effects on corporate philanthropy. It is expected that compared with those who have studied or worked in a country with a less-developed market structure, executives returning from a well-developed market structure are more likely to downplay the importance of corporate philanthropy in obtaining legitimacy. We strongly encourage future studies to explore the differential effects of executives with different overseas backgrounds on corporate market and nonmarket strategies. 
Second, while we have examined the effects of three moderating factors at the organizational level, the relationship between returnee executives and corporate philanthropy may also depend on institutional factors. For example, scholars could compare the effect of returnee executives on corporate philanthropy before and after China's Charity Law came into force in 2016. As the Charity Law is designed to protect the legitimate interests and rights of charitable donors, ${ }^{8}$ it may motivate returnee executives to increase corporate philanthropy, thus weakening the effect of returnee executives on corporate philanthropy. We encourage future research to explore more moderating factors at the institutional level.

Third, it is expected that executives with longer exposure to comprehensive CSR view in developed countries are more likely to downplay corporate philanthropy. Thus, the relationship between returnee executives and corporate philanthropy may depend on returnee executives' duration of staying abroad. Although data limitation prevented us from directly testing the role of returnee executives' duration of staying abroad, future research will benefit from considering this important factor. For example, although we found that executives' overseas work experience is not significantly related to corporate philanthropy, as long as executives' duration of work abroad is long enough, the effect of executives' overseas work experience on corporate philanthropy may become manifest.

Finally, our study was set in the Chinese context. Although China is one of the world's largest emerging economies, our results may not generalize to other emerging economies. A fruitful direction for future research would be to investigate whether our findings can be replicated in other emerging economies. More importantly, with cross-culture study, future research can explore the institutional factors that explain why returnees cause less philanthropy in some countries versus in others, and what are such country-level features should be looked at. For example, future research can explore the role of CSR development level of a country in explaining the effect of returnee executives on corporate philanthropy. It is expected that, in countries where CSR is underdeveloped and corporate philanthropy is highly valued than other CSR components, the effect of returnee executives on corporate philanthropy will be stronger. In addition, the regulations of charitable organizations may also matter. As returnee executives may view donating to governmentorganized charities as bribery, in countries with prevailing government-organized charitable organizations, the negative impact of returnee executives on corporate philanthropy may also be strengthened. Cross-country analysis of the proposed

\footnotetext{
8 https://www.cn.undp.org/content/china/en/home/library/democ ratic_governance/handbook-of-charity-law-of-the-peoples-republicof-china.html.
}

effects would enrich our understanding of the relationship between returnee executives and corporate philanthropy.

Funding This work was supported by the National Natural Science Foundation of China (No. 71902063), Major Program of the National Social Science Foundation of China (No. 21ZDA036, No. 18ZDA057, No. 18ZDA092), Basic and Applied Basic Research Fund of Guangdong Province (No. 2020A1515010043, No. 2021A1515011920), China Postdoctoral Science Foundation (No. 2020T130207). Lin Zhang declares that he has no conflict of interest. Yuehua Xu declares that she has no conflict of interest. Honghui Chen declares that he has no conflict of interest.

\section{Declarations}

Conflict of interest The authors declare that they have no conflict of interest.

Ethical Approval This article does not contain any studies with human participants or animals performed by any of the authors.

\section{References}

Adams, M., \& Hardwick, P. (1998). An analysis of corporate donations: United Kingdom evidence. Journal of Management Studies, 35(5), 641-654.

Aiken, L. S., \& West, S. G. (1991). Multiple regression: Testing and interpreting interactions. Sage.

Amaeshi, K. M., Adi, B. C., Ogbechie, C., \& Amao, O. O. (2006). Corporate social responsibility in Nigeria: Western mimicry or indigenous influences? Journal of Corporate Citizenship, 24(4), 83-99.

Amato, L. H., \& Amato, C. H. (2007). The effects of firm size and industry on corporate giving. Journal of Business Ethics, 72(3), 229-241.

Araujo, A., Chateauneuf, A., \& Faro, J. H. (2018). Financial market structures revealed by pricing rules: Efficient complete markets are prevalent. Journal of Economic Theory, 173(1), 257-288.

Barnett, M. L., \& Salomon, R. M. (2006). Beyond dichotomy: The curvilinear relationship between social responsibility and financial performance. Strategic Management Journal, 27(11), $1101-1122$.

Baron, D. P. (1995). Integrated strategy: Market and nonmarket components. California Management Review, 37(2), 47-65.

Beckman, C. M., \& Burton, M. D. (2011). Handbook of top management team research. Edward Elgar.

Belsley, D. A., Kuh, E., \& Welsch, R. E. (2005). Regression diagnostics-Identifying influential data and sources of collinearity. Wiley.

Bertrand, O., Betschinger, M. A., \& Moschieri, C. (2021). Are firms with foreign CEOs better citizens? A study of the impact of CEO foreignness on corporate social performance. Journal of International Business Studies, 52(3), 525-543.

Brammer, S., \& Millington, A. (2006). Firm size, organizational visibility and corporate philanthropy: An empirical analysis. Business Ethics: A European Review, 15(1), 6-18.

Briscoe, F., \& Safford, S. (2008). The Nixon-in-China effect: Activism, imitation and the institutionalization of contentious practices. Administrative Science Quarterly, 53(3), 460-491. 
Byron, K., \& Post, C. (2016). Women on boards of directors and corporate social performance: A meta-analysis. Corporate Governance: An International Review, 24(4), 428-442.

Cain, D. M., Moore, D. A., \& Haran, U. (2015). Making sense of overconfidence in market entry. Strategic Management Journal, $36(1), 1-18$

Campbell, J. L. (2004). Institutional change and globalization. Princeton University Press.

Cannella, A. A., Hambrick, D. C., \& Finkelstein, S. (2009). Strategic leadership: Theory and research on executives, top management teams, and boards. Oxford University Press.

Carpenter, M. A., Geletkanycz, M. A., \& Sanders, W. G. (2004). Upper echelons research revisited: Antecedents, elements, and consequences of top management team composition. Journal of Management, 30(6), 749-778.

Carroll, A. B. (1979). A three-dimensional conceptual model of corporate performance. Academy of Management Review, 4(4), 497-505.

Carroll, A. B. (1991). The pyramid of corporate social responsibility: Toward the moral management of organizational stakeholders. Business Horizons, 34(4), 39-48.

Carroll, A. B. (2008). The Oxford handbook of corporate social responsibility. Oxford University Press.

Cragg, J. G., \& Donald, S. G. (1993). Testing identifiability and specification in instrumental variable models. Econometric Theory, 9(2), 222-240.

Crane, A., \& Matten, D. (2007). Business ethics (2nd ed.). Oxford University Press.

Dahlsrud, A. (2008). How corporate social responsibility is defined: An analysis of 37 definitions. Corporate Social Responsibility and Environmental Management, 15(1), 1-13.

Dai, O., \& Liu, X. (2009). Returnee entrepreneurs and firm performance in Chinese high-technology industries. International Business Review, 18(4), 373-386.

Dennis, B. S., Buchholtz, A. K., \& Butts, M. M. (2009). The nature of giving: A theory of planned behavior examination of corporate philanthropy. Business \& Society, 48(3), 360-384.

Dickson, B. J. (2003). Red capitalists in China: The party, private entrepreneurs, and prospects for political change. Cambridge University Press.

Du, X., Jian, W., Du, Y., Feng, W., \& Zeng, Q. (2014). Religion, the nature of ultimate owner, and corporate philanthropic giving: Evidence from China. Journal of Business Ethics, 123(2), 235-256.

Edelman, L. B. (1992). Legal ambiguity and symbolic structures: Organizational mediation of civil rights law. American Journal of Sociology, 97(6), 1531-1576.

Faccio, M. (2010). Differences between politically connected and nonconnected firms: A cross-country analysis. Financial Management, 39(3), 905-928

Fan, J. P. H., Wong, T. J., \& Zhang, T. Y. (2007). Politically connected CEOs, corporate governance, and Post-IPO performance of China's newly partially privatized firms. Journal of Financial Economics, 84(2), 330-357.

Feng, X. (2015). China's charitable foundations: Development and policy-related issues. Chinese Economy, 48(2), 130-154.

Fergusson, M. J., \& Mcguinness, P. B. (2004). Chinese securities reform: The role of QFII in the corporate governance process. Business Horizons, 47(2), 53-61.

Filatotchev, I., Liu, X., Buck, T., \& Wright, M. (2009). The export orientation and export performance of high-technology SMEs in emerging markets: The effects of knowledge transfer by returnee entrepreneurs. Journal of International Business Studies, 40(6), 1005-1021.
Finkelstein, S. (1992). Power in top management teams: Dimensions, measurement, and validation. Academy of Management Journal, 35(3), 505-538.

Finkelstein, S., \& Hambrick, D. C. (1990). Top management team tenure and organizational outcomes: The moderating role of managerial discretion. Administrative Science Quarterly, $35(3), 484-550$.

Finkelstein, S., \& Hambrick, D. C. (1996). Strategic leadership: Top executives and their effects on organizations. South-Western Pub.

Freeman, R. E. (1984). Strategic management: A stakeholder approach. Cambridge University Press.

Freeman, R. E. (1999). Divergent stakeholder theory. Academy of Management Review, 24(2), 233-236.

Fry, L. W., Keim, G. D., \& Meiners, R. E. (1982). Corporate contributions: Altruistic or for-profit? Academy of Management Journal, 25(1), 94-106

Galaskiewicz, J. (1997). An urban grants economy revisited: Corporate charitable contributions in the twin cities, 1979-81, 1987-89. Administrative Science Quarterly, 42(3), 445-471.

Gao, Y. (2006). Corporate political action in China and America: A comparative perspective. Journal of Public Affairs, 6(2), 111-121.

Gao, Y. (2011). Philanthropic disaster relief giving as a response to institutional pressure: Evidence from China. Journal of Business Research, 64(12), 1377-1382.

Gao, Y., \& Hafsi, T. (2015). Government intervention, peers' giving and corporate philanthropy: Evidence from Chinese private SMEs. Journal of Business Ethics, 132(2), 1-15.

Garriga, E., \& Mele, D. N. (2004). Corporate social responsibility theories: Mapping the territory. Journal of Business Ethics, 53(1-2), 51-71.

Gautier, A., \& Pache, A. C. (2015). Research on corporate philanthropy: A review and assessment. Journal of Business Ethics, 126(3), 343-369.

Giannetti, M., Liao, G., \& Yu, X. (2015). The brain gain of corporate boards: Evidence from China. The Journal of Finance, 70(4), $1629-1682$

Gong, G., Huang, X., Wu, S., Tian, H., \& Li, W. (2021). Punishment by securities regulators, corporate social responsibility and the cost of debt. Journal of Business Ethics, 171(2), 337-356.

Gul, F. A., Lynn, S. G., \& Tsui, J. S. L. (2002). Audit quality, management ownership, and the informativeness of accounting earnings. Journal of Accounting Auditing \& Finance, 17(1), 25-50.

Hambrick, D. C. (2007). Upper echelons theory: An update. Academy of Management Review, 32(2), 334-343.

Hambrick, D. C., \& Finkelstein, S. (1987). Managerial discretion: A bridge between polar views of organizational outcomes. Research in Organizational Behavior, 9(4), 369-406.

Hambrick, D. C., \& Mason, P. A. (1984). Upper echelons: The organization as a reflection of its top managers. Academy of Management Review, 9(2), 193-206.

Han, Q., Jennings, J. E., Liu, R., \& Jennings, P. D. (2019). Going home and helping out? Returnees as propagators of CSR in an emerging economy. Journal of International Business Studies, 50(4), 857-872.

He, Y., Tian, Z., \& Chen, Y. (2007). Performance implications of nonmarket strategy in China. Asia Pacific Journal of Management, 24(2), 151-169.

Jia, M., \& Zhang, Z. (2013). Managerial ownership and corporate social performance: Evidence from privately owned Chinese firms' response to the Sichuan earthquake. Corporate Social Responsibility and Environmental Management, 20(5), 257-274.

Jo, H., \& Harjoto, M. A. (2011). Corporate governance and firm value: The impact of corporate social responsibility. Journal of Business Ethics, 103(3), 351-383. 
Johnson, R. A., \& Greening, D. W. (1999). The effects of corporate governance and institutional ownership types on corporate social performance. Academy of Management Journal, 42(5), 564-576.

Koch-Bayram, I. F., \& Wernicke, G. (2018). Drilled to obey? Exmilitary CEOs and financial misconduct. Strategic Management Journal, 39(11), 2943-2964.

Kor, Y. Y. (2006). Direct and interaction effects of top management team and board compositions on R\&D investment strategy. Strategic Management Journal, 27(11), 1081-1099.

Kusku, F., \& Zarkada-Fraser, A. (2004). An empirical investigation of corporate citizenship in Australia and Turkey. British Journal of Management, 15(1), 57-72.

Lee, M. D. P. (2008). A review of the theories of corporate social responsibility: Its evolutionary path and the road ahead. International Journal of Management Reviews, 10(1), 53-73.

Li, S., Song, X., \& Wu, H. (2015). Political connection, ownership structure, and corporate philanthropy in china: A strategic-political perspective. Journal of Business Ethics, 129(2), 399-411.

Li, J., \& Tang, Y. (2010). CEO hubris and firm risk taking in China: The moderating role of managerial discretion. Academy of Management Journal, 53(1), 45-68.

Li, S. X., Yao, X. T., Sue-Chan, C., \& Xi, Y. M. (2011). Where do social ties come from: Institutional framework and governmental tie distribution among Chinese managers. Management and Organization Review, 7(1), 97-124.

Li, H., Zhang, Y., Li, Y., Zhou, L. A., \& Zhang, W. (2012). Returnees versus locals: Who perform better in China's technology entrepreneurship? Strategic Entrepreneurship Journal, 6(6), 257-272.

Li, S. H., Chen, X., \& Song, X. Z. (2016). Generosity from the pool: Study on firms' strategic motivation. Management World, 32(5), 116-127. (in Chinese).

Lin, D., Lu, J., Liu, X., Choi, S. J., Lin, D., \& Lu, J. (2014). Returnee CEO and innovation in Chinese high-tech SMEs. International Journal of Technology Management, 65(1/2/3/4), 151-171.

Lin, D., Lu, J., Liu, X., \& Zhang, X. (2016). International knowledge brokerage and returnees' entrepreneurial decisions. Journal of International Business Studies, 47(3), 295-318.

Lin, T. L., Liu, H. Y., Huang, C. J., \& Chen, Y. C. (2018). Ownership structure, board gender diversity and charitable donation. Corporate Governance, 18(4), 655-670.

Lindgreen, A., Swaen, V., \& Campbell, T. T. (2009). Corporate social responsibility: An empirical investigation of U.S. organizations. Journal of Business Ethics, 85(4), 303-323.

Lindgreen, A., Swaen, V., \& Johnston, W. J. (2009a). Corporate social responsibility practices in developing and transitional countries: Botswana and Malawi. Journal of Business Ethics, 90(2), 429-440.

Liu, X., Lu, J., Filatotchev, I., Buck, T., \& Wright, M. (2010). Returnee entrepreneurs, knowledge spillovers and innovation in high-tech firms in emerging economies. Journal of International Business Studies, 41(7), 1183-1197.

Liu, Y., Dai, W., Liao, M., \& Wei, J. (2021). Social status and corporate social responsibility: Evidence from Chinese privately owned firms. Journal of Business Ethics, 169(4), 651-672.

Ma, D., \& Parish, W. L. (2006). Tocquevillian moments: Charitable contributions by Chinese private entrepreneurs. Social Forces, 85(2), 943-964.

Maon, F., Lindgreen, A., \& Swaen, V. (2009). Designing and implementing corporate social responsibility: An integrative framework grounded in theory and practice. Journal of Business Ethics, 87(6), 71-89.

March, J. G., \& Simon, H. (1958). Organizations. Wiley.

McGuinness, P. B., Vieito, J. P., \& Wang, M. (2017). The role of board gender and foreign ownership in the CSR performance of Chinese listed firms. Journal of Corporate Finance, 42(2), 75-99.
Mellahi, K., Frynas, J. G., Sun, P., \& Siegel, D. S. (2016). A review of the nonmarket strategy literature: Toward a multi-theoretical integration. Journal of Management, 42(1), 143-173.

Mishina, Y., Dykes, B. J., Block, E. S., \& Pollock, T. G. (2010). Why "good" firms do bad things: The effects of high aspirations, high expectations, and prominence on the incidence of corporate illegality. Academy of Management Journal, 53(4), 701-722.

Morck, R., Shleifer, A., \& Vishny, R. W. (1988). Management ownership and firm value: An empirical analysis. Journal of Financial Economics, 20(1-2), 293-315.

Muller, A., \& Whiteman, G. (2009). Exploring the geography of corporate philanthropic disaster response: A study of Fortune Global 500 firms. Journal of Business Ethics, 84(4), 589-603.

Nagao, C. (1998). Where to belong?: An empirical study of the cultural identity of Japanese children overseas, Unpublished doctoral dissertation, Harvard University, Boston, MA.

Nee, V. (1992). Organizational dynamics of market transition: Hybrid forms property rights, and mixed economy in China. Administrative Science Quarterly, 37(1), 1-27.

Neter, J., Kutner, M. H., Nachtsheim, C. J., \& Wasserman, W. (1996). Applied linear statistical models. Irwin Chicago.

Park, S. H., \& Luo, Y. (2001). Guanxi and organizational dynamics: Organizational networking in Chinese firms. Strategic Management Journal, 22(5), 455-477.

Pollock, T. G., \& Gulati, R. (2007). Standing out from the crowd: The visibility-enhancing effects of IPO-related signals on alliance formation by entrepreneurial firms. Strategic Organization, 5(4), 339-372.

Porter, M. E., \& Kramer, M. R. (1999). Philanthropy's new agenda: Creating value. Harvard Business Review, 77(6), 121-130.

Rindova, V. P., Williamson, I. O., Petkova, A. P., \& Sever, J. M. (2005). Being good or being known: An empirical examination of the dimensions, antecedents, and consequences of organizational reputation. Academy of Management Journal, 48(6), 1033-1049.

Sarkar, S., \& Searcy, C. (2016). Zeitgeist or chameleon? A quantitative analysis of CSR definitions. Journal of Cleaner Production, 135(11), 1423-1435.

Singh, P. J., Sethuraman, K., \& Lam, J. Y. (2017). Impact of corporate social responsibility dimensions on firm value: Some evidence from Hong Kong and China. Sustainability, 9(9), 1532-1256.

Smith, W., Wokutch, R., Harrington, K., \& Dennis, B. (2001). An examination of the influence of diversity and stakeholder role on corporate social orientation. Business and Society, 40(3), 266-294.

Souitaris, V., \& Maestro, B. M. (2010). Polychronicity in top management teams: The impact on strategic decision processes and performance of new technology ventures. Strategic Management Journal, 31(6), 652-678.

Tam, O. K., Li, S. G., Zhang, Z., \& Yu, C. P. (2010). Foreign investment in China and qualified foreign institutional investor (qfii). Asian Business \& Management, 9(3), 425-448.

Tang, Y., Mack, D. Z., \& Chen, G. (2018). The differential effects of CEO narcissism and hubris on corporate social responsibility. Strategic Management Journal, 39(3), 1370-1387.

Tang, Y., Qian, C., Chen, G., \& Shen, R. (2015). How CEO hubris affects corporate social (ir)responsibility. Strategic Management Journal, 36(9), 1338-1357.

Waddock, S. A., \& Graves, S. B. (1997). The corporate social performance-financial performance link. Strategic Management Journal, 18(4), 303-319.

Walls, J. L., Berrone, P., \& Phan, P. H. (2012). Corporate governance and environmental performance: Is there really a link? Strategic Management Journal, 33(8), 885-913.

Wang, H., \& Qian, C. (2011). Corporate philanthropy and corporate financial performance: The roles of stakeholder response 
and political access. Academy of Management Journal, 54(6), 1159-1181.

Wang, H., Tong, L., Takeuchi, R., \& George, G. (2016). Corporate social responsibility: An overview and new research directions. Academy of Management Journal, 59(2), 534-544.

Wang, J., Ceng, B., \& Sun, L. (2014). Performance feedback on R\&D and corporate philanthropy. Management World, 30(8), 115-133. (in Chinese).

Wang, J., \& Dewhirst, H. D. (1992). Boards of directors and stakeholder orientation. Journal of Business Ethics, 11(2), 115-123.

Wang, Q., Wong, T. J., \& Xia, L. J. (2008). State ownership, the institutional environment, and auditor choice: Evidence from China. Journal of Accounting \& Economics, 46(1), 112-134.

Williams, R. J. (2003). Women on corporate boards of directors and their influence on corporate philanthropy. Journal of Business Ethics, 42(1), 1-10.

Wood, D. J. (1991). Corporate social performance revisited. Academy of Management Review, 16(4), 691-718.

Wooldridge, J. M. (2003). Econometric analysis of cross section and panel data. MIT Press.

Wright, M., Liu, X., Buck, T., \& Filatotchev, I. (2008). Returnee entrepreneurs, science park location choice and performance: An analysis of high-technology SMEs in China. Entrepreneurship Theory and Practice, 32(1), 131-155.

Wu, L. Z., Kwan, H. K., Yim, H. K., Chiu, R. K., \& He, X. (2015). CEO ethical leadership and corporate social responsibility: A moderated mediation model. Journal of Business Ethics, 130(4), 819-831.
Yiu, D. W., Xu, Y., \& Wan, W. P. (2014). The deterrence effects of vicarious punishments on corporate financial fraud. Organization Science, 25(5), 1549-1571.

Zhang, J., Kong, D., \& Wu, J. (2018). Doing good business by hiring directors with foreign experience. Journal of Business Ethics, 153(3), 859-876.

Zhang, J., Marquis, C., \& Qiao, K. (2016). Do political connections buffer firms from or bind firms to the government? A study of corporate charitable donations of Chinese firms. Organization Science, 27(5), 1307-1324.

Zhang, L., Xu, Y., Chen, H., \& Jing, R. (2020). Corporate philanthropy after fraud punishment: An institutional perspective. Management and Organization Review, 16(1), 33-68.

Zhang, Z., Wang, X., \& Jia, M. (2021). Echoes of CEO entrepreneurial orientation: How and when CEO entrepreneurial orientation influences dual CSR activities. Journal of Business Ethics, 169(4), 609-629.

Zhong, M., Xu, R., Liao, X., \& Zhang, S. (2019). Do CSR ratings converge in China? A comparison between RKS and Hexun scores. Sustainability, 11(14), 3921-3941.

Zhongguancun Science Park Management Committee. (2006). Zhongguancun Science Park development report. Zhongguancun Science Park Management Committee.

Publisher's Note Springer Nature remains neutral with regard to jurisdictional claims in published maps and institutional affiliations. 